\title{
日本臨床獣医学会昭和 38 年度褒賞論文要旨
}

第91回日本臨床獣医学会 (総会) 期日 : 昭和 38 年 4 月 10 日 会場 : 東京都, 獣医師会館

イオン導入法による乳房炎治療成績について

丸尾春雄* 笹原和三* 浅井 稔林 岩崎武雄***

今日尚難治の乳房炎が多く，われわれ臨床家を悩して いる．研究者はその原因は病原体に対する薬物不適応ま たは酎性菌によると説くが，今日われわれの用いている 乳房炎治療薬のほとんどは広い抗菌スペクトルをもつ混 合剂であり，また指示の数倍以上の薬量を使用している 現状からはなはだ納得し難い，そもそも乳房は元来分泌 作用を行なら巨大な臓器で乳腺胞から分泌された乳汁が 集合, 下行して排出される経路はきわめて複雑であり, 発炎すればそれらが腫脹, 狭窄し, 内に膿汁, 凝乳など がつまり, 乳槽に注入された薬液の上行, 浸潤が困難で あるといらことに注目すべきである。薬物は単に拡散と 毛管現象で到達した粘膜面のみから唀または吸収され て粘膜下織に達し,静脈またはリン;流に入り,求心的に 移行してしまい, 病巣への直接浸潤がきわめて少ないこ とは明白である．宮沢は乳房炎難治の主な理由はこの薬 物応用法の欠陥にあるとし，乳槽内に注入した薬物を低 周波電流により, 組織内に導入する療法すなわら, イオ ン導入法を初めて牛に実験し, 安全かつ容易に行なえ, 重症の乳房炎を完治させたことを 1961 年秋の日本獣医 学会に報告している.われわれは 1962 年 5 月以来主と して重症执よびしばしば発症する碩症の乳房炎患乳に追 試し，顕著な治療成績を得たので報告する.

\section{イオン導入法の理論}

生体と薬液を接触させ, 電極をそれぞれ薬液と生体に つけて電流回路につなぐと, 生体側電極に向う薬剤イオ ンは組織内深く浸透する理論を応用する治療法をいう。

\section{用いた装置と通電法}

平和電子研究所製の動物用直角脈波低周電流治療器了 ニペットを用いた： $20 \mathrm{~mA}$ 出力の強力なものであるが携 带型で，電源は家庭用電灯線よりとり，周波数を 2,000 とし, 電流調節器のつまみを零にしておく. 患乳房に薬 剤を注入した後, 細い銀の棒状電極を乳頭口にさしこ み, 乳首にバンドでとめ, つぎに腰筋部被毛に温湯をす りこみ, ぬれタオルを置き, その上に広い平板電極を載 せ：ゴムバンドで胴に巻き止める. 最後にアニペットの 出力側コードの陰極を乳房電極に, 陽極を腰部電極につ ないで準備を終る。

通電は電流量調節器のツマミをゆっくり右に廻して行 なら、電流計の針がふれ始める. 牛が電流刺激を感じは

\footnotetext{
* 静岡県開業，** 静岡市農業共済組合

*** 韮山町農業共済組合
}

日獣会誌 18 (1965)
じめたときは約 1 分，そのますにすると鈍感になるので 再び上昇させる。

つまり不快を示すと休み，また再び上昇させるといら ことを繰り返しつつ 15〜20 mA に上げることができ る. この状態で 20〜30 分, 導入し, 電流量調節器のッ マミをゆっくり元に戻して零とし, スイッチを切り, 治 療を終る. 生体は蓄電池化しその後も約 $3 \mathrm{~mA}$ 位の電流 の流れがあり，導入効果は相等持続する.

\section{治療に用神を薬戍}

ペニシリン. ペニコリマイシン, 、スシリン, サルマ イFなどを用い, 水溶液のものは $50 \sim 100 \mathrm{cc}$ の蒸留水に 溶いて用いた。

\section{治療判定}

一部細菌培養したものの他は黒布法, 乳房炎試験紙括 よびPLテスターを用い乳汁および乳房の肉眼的経過を 観察し，20日後にP Lテスターで判定した.

\section{症例和よび治療成績}

三島市近郊および静岡市付近で 1962 年 5 月より 63 年 2 月までの患牛 30 頭についてつぎのごとき成績を得 た. 急性および亜急性のもの 17 頭，うち本法を直ぐ施 したものは 4 頭でいずれも分娭直後の重症のものであっ た. 他は $2 \sim 6$ 日間従来の療法の末, 症状の改変または 軽快しないため，イオン導入した頑症である.13頭の慢 性症もしばしば発症していた厄介なものである. 1 日 1 回 20〜30 分通電し連続 $3 \sim 4$ 日を 1 クールとしその経 過を観察した。

橙黄色水溶液を出していたもので中には直ちに乳白化 したものもあったが，多くは腫脹が軟化，軽減し，漸次 搾取液が乳色を帯びてきて, ブッが減少しついで乳白化 し, 乳量が増加するといら経過を示した。細菌培養を行 なった 5 頭では菌陰性のため乳汁は悪いが，そのまま観 察したところ, 腫脹が減退, 軟化しはじめ, $1 \sim 6$ 日, おとくとも10 日後には黒布法, 乳房炎試験紙の反応が 㓌性となった. 慢性症でも本法終了後なお 2 ～ 4 日ブッ が出るものもあったが 1 週間後には正常となり, 初期症 例で10力月, 最後のもので 1 力月を経過しているが再発 をみない。

泌乳最盛期に右前後乳房の疼痛顕著, 跛行し, 食欲廃 絶といら重篤な症状を示し, 橙黄色液少量を分泌する状 態が 6 日間不変のため, ペニシリン 200 万単位, 3 日間 イオン導入したところ, 疼痛消散し食欲良好となり, 1 
週間後には軟化縮少し，健側の泌乳が旺盛となったが患 側は萎縮, 閉止した。すなわち消炎したが泌乳力は回復 乙得なかった。本例以外は 20 日後のP Lテスターその 他が陰性で回復と認めた.

\section{むすび}

われわれは 30 例の乳房炎をイオン導入法により治 療し，つぎのごとき成績を得た。

1. 牛乳房は 15 20 mA の低周波通電に耐え, 何ら の副作用や危険を認めない.

2. 分娩直後の重症例が全例治癒し, 他の急, 慢性症 も完治し再発をみない，ただ本療法開始の遅れた急性症
1 例のみが消炎はしたが泌乳閉止に終ったといら結果で ある。

3. 以上の成績から本療法が「治療薬をよく病巣に導 入するとともに低周波電流の消炎，鎮痛作用が相乗され 治瘳させる」という宮沢の報告に同意するものである.

4. 通電時間については一応 $20 \sim 30$ 分としたが, 今 後短縮し，使用薬品の減少をはかりたい。

終りにご指導をいただいた静岡県農共連宮沢正憲博士 に感謝申し上げるとともに装置アニペットを貸与された フジモト薬品 $\mathrm{KK}$ ，および平和電子研究所に謝意を表し ます。

第92回日本臨床獣医学会 (関東) 期日：昭和38年 6 月 11 日 会場 $:$ 鎌倉市, 公会堂

\section{乳牛卵巣のう腫に対する HCG 卵巣実質内注射による治療試験}

\section{入江達彦* 渡辺高俊* 鈴木洋治* 高梨 昭* 樺山洋吉*}

乳牛の卵巣疾患に対して現在性腺刺激ホルモン剂の応 用が治療の中心をなし皮下, 筋肉, 静脈内注射が実施さ れてきた. PAREDIS (1953)が卵巣のう腫の治療に腟壁よ りのう腫沪胞内に性腺刺激ホルモン 250 1,000 IUの注 射によって 80 例中 52 例 $(65 \%)$. 治熦を報告し，その 後 VEREERFUGGEN (1957) は 56 例の思牡狂牛治療に $750 \sim 1,250 \mathrm{IU}$ の沪胞内注入により $78.4 \%$ の治痖率を 報告し, ROBERTs（1957）は 17 例の沪胞のう腫牛の治 療に批いて 250〜2,500 IU の注射で $76.4 \%$ が治瘾した と報告している. ROBERTS はこれらの結果より直接注射 の傷害の認められないこと, ホルモンの単位が少量にて のう腫が治瘾できたと報告している。わが国に扒いては 小野寺ら (1956) は HCG 1,000 1,250 MU を用いて 14例中 9 例 $(64 \%)$ が受胎したと報告し, 山内ら(1959) による Anti-HCG 研究と併行して HCG をのう腫内に 直接注射する治療を試み, のう腫牛 10 頭に 1 卵巣当り 平均 $3,540 \mathrm{MU}$ の $\mathrm{HCG}$ を直接のう腫内に注入乙従来 の皮下, 筋肉注射飞比し少量の HCG で治療効果を期待 乙得ることを報告し,その後定森ら(1962), 塚田ら(1962) による2,000 MUによる報告がある。また卵巣疾患注対 する APG の卵巣実質内直接注射の報告は檜垣ら (1961) の報告がある。

著者らは汇胞のう腫に対して HCG の低単位を直接卵 巣実質内注射による臨床所見の結果つぎのような臨床成 績を得たので報告する。

\section{1. 供試牛和よび試験方法}

供試牛：1962年 2 月から 1963 年 3 月まで当地区家 畜部療所管内に执いて臨床所見（外部徵候，直腸検査） の結果沪胞のう腫と診断された 25 例を供試牛とした。

\footnotetext{
* 千葉県農業共済組合連合会平郡地区家畜診療所
}

供試牛はいずれもホルスタイン種雌牛およびホルスタイ ン系種雌牛である。

試験方法 : HCG 剂（水性プベローゲン） $500 \mathrm{MU}$ $1 \mathrm{cc}$ 生理食塩液に溶解, 檜垣式卵巣注射器にて所定の 方法により卵巣実質内注射を実施し，ホルモン剂の併用 は行なわなかった。注射時沪胞破碎を原則とし，実質内 注射は 1 側性沪胞のう腫はのう腫側に, 両側性沪胞のう 腫に対しては 1 側に実質内注射を実施し，卵巣，子宮を 観察した. 子宮内薬液注入は子宮内膜炎と診断されたも のには抗生物質剂を併用した。

\section{2. 試 験 成 績（表 1 参照）}

注射後のう腫の黄体化を認め注射後 7 34日平均 20.5 日で正常発情を認め, 初回注射で効果のあったもの 25 例 中 17 例 $(68.0 \%), 2$ 回注射で効果のあったもの 25 例 中 22 例 $(88.0 \%), 3$ 回注射で効果のあったもの 25 例 中 25 例 $(100 \%)$ の治療効果を認め, 受胎頭数 25 例中

表 1 HCG 500 MU 卵巣実質内注射辸沪 胞のう腫治療成績表

\begin{tabular}{|c|c|c|c|}
\hline 沪胞のう腫の区分 & 1 側性 & 両側性 & 計 \\
\hline 頭 & 11 & 14 & 25 \\
\hline $\begin{array}{l}\text { 初回注射で効果 } \\
\text { のあったも頭数 } \\
\%\end{array}$ & $\begin{array}{c}8 \\
72.7\end{array}$ & $\begin{array}{c}9 \\
64.3\end{array}$ & $\begin{array}{l}17 \\
68.0\end{array}$ \\
\hline $\begin{array}{l}2 \text { 回注射で効果 } \\
\text { のあったも頭数 } \\
\%\end{array}$ & $\begin{array}{l}10 \\
90.9\end{array}$ & $\begin{array}{l}12 \\
85.7\end{array}$ & $\begin{array}{l}22 \\
88.0\end{array}$ \\
\hline 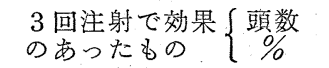 & $\begin{array}{r}11 \\
100\end{array}$ & $\begin{array}{r}14 \\
100\end{array}$ & $\begin{array}{r}25 \\
100\end{array}$ \\
\hline 受 胎 頭 数 & 7 & 11 & 18 \\
\hline 受胎率 & 63.6 & 78.6 & $72.0 \%$ \\
\hline *受胎迄に要した日次 & 55.3 & 30.4 & 40.1 日 \\
\hline 受胎迄に要した授精回数 & 2.3 & 1.4 & 1.5回 \\
\hline
\end{tabular}

註 $: *$ 最終注射後の日次 
18例，受胎率 $72.0 \%$ であった。受胎までに要した日次 は 15 149日平均 40.1 日，受胎まで要した授精回数 平均 1.5 回であった. 不受胎 25 例中 7 例の内訳は卵巣 機能減退症 5 例, 子宮内膜炎 1 例, 転売 1 例である.

\section{3. 考察}

HCG 500 MU の卵巣実質内注射は乳牛汇胞のう腫に 治癒効果が認められ，注射後汇胞の黄体化とともに平均 20.5日で正常初回発情を認め, PAREDIS, 小野寺ら，山内 らの沪胞内注射とほぼ一致した成績を認め, 受胎までに 要した日数は最終的注射後平均 40.1 日で従来報告され ている高単位使用による場合と差は認められず有効であ ったと思う。

つぎに注射回数は HCG $500 \mathrm{MU} 1 \sim 2$ 回注射で 25例 中 22 例 $(88.0 \%)$ の治痖効果を認めた. HCG の使用単 位量は沪胞内注入による成績は VEREERTBRUGGEN は750 $\sim 1,250$ IU. PAREDIS \& 250 1,000 IU，ROBERTSは250 $\sim 2,500 \mathrm{IU}$ ，小野寺らは 1,000 1,250 MU，山内らは 1 畉巣当り平均 $3,540 \mathrm{MU}$, 定森ら, 塚田らに上る 2,000 MUの報告がある。著者らは HCG の低単位を直接卵巣 実質内注射乙使用単位を低くし乳牛汇胞のう腫に有効で あったことを認めた．HCG 1,000〜2,000 MUの卵巣実 質内注射を乳牛の沪胞のう腫飞試みた結果畉栄実質の硬 結を認め，使用単位 HCG 500MU を試及た結果卵巣実
質の硬結も認められなく卵巣実質注射においては安定さ れた使用単位と推察する. 受胎率は 25 例中 18 例 $(72.0$ \%)で沪胞内注射の報告とほぼ一致した成績を得た。

実質内注射の方法は薬液が完全に実質内に注射される ことが肝要と思う。

\section{4. 結言}

1962年 2 月から 1963 年 3 月の間に当地区家畜診療所 管内に発生した乳牛汇胞のう腫牛 25 例に対して $\mathrm{HCG}$ 剂 500MU の卵栄実質内注射による治療試験よりつぎの 結論を得た。

1. HCG $500 \mathrm{MU}$ の $1 \sim 3$ 回卵巣実質内注射により 沪胞のら腫の治瘾経過が認められた.

2. 治痖までの日数が汇胞内注射に比し遜色は認めら れない。

3. 注射による副作用，たとえば卵巣硬結，注射によ るショックが認められない。

4. 低単位使用による治療費の節減により実用価値あ るものと認める.

以上報告を終るにあたり今後の問題点として， HCG の使用単位をさらに低くして卵巣実質内注射を試みた場 合の卵巣動態の観察, 溶解液の量的問題などについて試 験を続けたいと思っている。

（文献省略）

第93回日本臨床獣医学会 (中部) 期日 : 昭和 38 年 7 月 12 日 会場 : 富山市, 北日本新聞社ホール

豚の浮腫病様疾患の発生例について

土倉道之* 林 和夫* 桑島至郎*

1962 年 7 月から 1963 年 5 月にわたり病性鑑定の依頼 をらけた病例のうちに，豚の浮腫病ときわ的て類似した 所見を示す少数例を見出したのでその概況を報告する.

1. 発生の概況

第 1 表 発 生 概 況

\begin{tabular}{|c|c|c|c|c|c|c|c|}
\hline 発 生 場 所 & $\begin{array}{l}\text { 発 } \\
\text { 生月 } \\
\text { 局 } \\
\text { 数 }\end{array}$ & $\begin{array}{l}\text { 飼 } \\
\text { 育 } \\
\text { 頭 } \\
\text { 数 }\end{array}$ & $\begin{array}{l}\text { 発 } \\
\text { 病 } \\
\text { 頭 } \\
\text { 数 }\end{array}$ & $\begin{array}{l}\text { 死 } \\
\text { 死 }\end{array}$ & 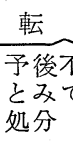 & 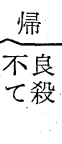 & 癒 \\
\hline 中新川郡立山町 $\mathrm{A}$ & $22 / 9$ & 5 & 2 & 1 & & 1 & 0 \\
\hline 上新川郡大山町 B & $118 / 9 \sim 26 / 9$ & 19 & 4 & 1 & & 1 . & 2 \\
\hline \multirow{2}{*}{$\begin{array}{c}\text { 射 水 郡小杉町 C } \\
\text { 計 }\end{array}$} & $129 / 4 \sim 30$ & 52 & 3 & 2 & & 0 & 1 \\
\hline & 3 & 76 & 9 & 4 & & 2 & 3 \\
\hline
\end{tabular}

1）第1表に示すように 3 地区においてそれぞれ 1 畜 舎づつ単発した。Aは種豚場を経営し，Bは専門の技術 者のもとに実習生が教材として飼養管理し，Cは肉豚を 多頭飼育する農家である。

* 富山県中央家畜保健衛生所

日獣会誌 18 (1965)
2) 発病豚の状況

発病豚の状況は第 2 表のとおりである.

2. 飼養管理. 畜舎環境および給与飼料は第 3 表のと おり。

A, B は飼養, 経営内容ともに付近の一般飼養農家に 較べて良好であり，Cは普通である。

\section{3. 臨床症状}

主要な臨床症状を第 4 表に示す.

全例に共通の症状は突然食欲不振または癈絶すること である。

\section{4. 血液検査所見}

2 例について行なった血液検査の結果は第 5 表のと拉 りである。

\section{5. 細菌検査成績}

4 号豚の胃, 十二指腸内容预よび腸間膜リンパ節より 溶血性の大腸菌を検出したが同定までにいたらなかっ た。

\section{6. 病理解剖所見}


第 2 表 発 病 豚 の 状 況

\begin{tabular}{|c|c|c|c|c|c|c|c|c|c|c|c|c|c|c|c|}
\hline \multirow{2}{*}{$\begin{array}{l}\text { 発生 } \\
\text { 場所 }\end{array}$} & \multirow{2}{*}{$\begin{array}{l}\text { 豚 } \\
\text { 番号 }\end{array}$} & \multirow[b]{2}{*}{ 品 } & \multirow{2}{*}{ 種 } & \multirow{2}{*}{ 性 } & \multirow{2}{*}{ 年 令 } & \multirow{2}{*}{ 産 地 } & \multirow{2}{*}{ 導入月日 } & \multirow{2}{*}{$\begin{array}{l}\text { 体重 } \\
(\mathrm{kg})\end{array}$} & \multirow{2}{*}{$\begin{array}{l}\text { 発病 } \\
\text { 月日 }\end{array}$} & \multicolumn{3}{|c|}{ 転帰 } & \multirow{2}{*}{\multicolumn{3}{|c|}{ 治療の有無 }} \\
\hline & & & & & & & & & & 月日 & 区 分 & 経過 & & & \\
\hline \multirow{3}{*}{$\mathrm{A}\{$} & 1 & & $v-y$ & 雄 & 37.1 生 & 埼玉県 & 37.5 & 130 & $29 / 7$ & $6 / 8$ & へい死 & 8日 & 治 & & 療 \\
\hline & 2 & & " & $"$ & 37.2 & 県 内 & 37.8 .24 & 100 & $16 / 9$ & $22 / 9$ & 殺処分 & 6 & & $" \prime$ & \\
\hline & 3 & 中ヨ - & クシヤ種 & 妵 & 37.3 .20 & $n$ & $37,4,30$ & 75 & $18 / 9$ & $19 / 9$ & へい死 & 0.5 & 無 & 処 & 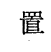 \\
\hline \multirow{4}{*}{ B } & 4 & & " & " & "I & 7 & 7 & $"$ & $24 / 9$ & $25 / 9$ & 殺処分 & 1.5 & 治 & & 療 \\
\hline & 5 & & " & $n$ & $n$ & " & 7 & 7 & $25 / 9$ & $3 / 10$ & 治 癒 & 8 & \multicolumn{3}{|c|}{ 早期治療開始 } \\
\hline & 6 & & " & $n$ & " & $n$ & $n$ & " & $26 / 9$ & $1 / 10$ & " & 5 & \multicolumn{3}{|c|}{ " } \\
\hline & 7 & $\phi=-$ & クシヤ種 & ぬき & 38.3. 8 & 県 内 & 38.4 .22 & 26 & $29 / 4$ & $30 / 4$ & へい死 & 1 & 治 & & 療 \\
\hline \multirow[t]{2}{*}{$\mathrm{C}$} & 8 & & $"$ & $n$ & $"$ & 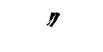 & 7 & $"$ & $30 / 4$ & $1 / 5$ & $"$ & 1 & & 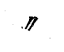 & \\
\hline & 9 & & $"$ & 雌 & $n$ & 7 & 7 & $n$ & $n$ & $6 / 5$ & 治 & 6 & 早期 & 治療 & 始 \\
\hline
\end{tabular}

第 3 表 飼養管理, 畜舎環境および給与飼料

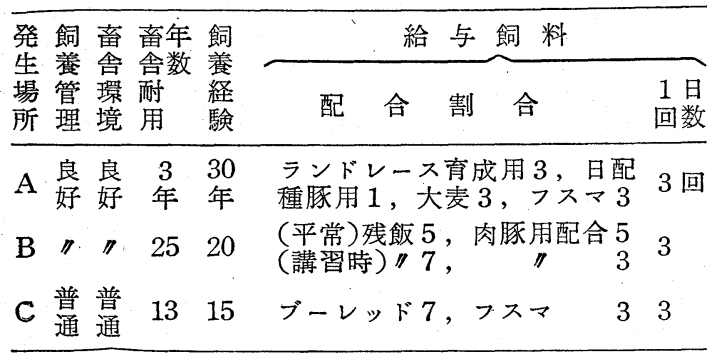

第 4 表 臨 床 症 状

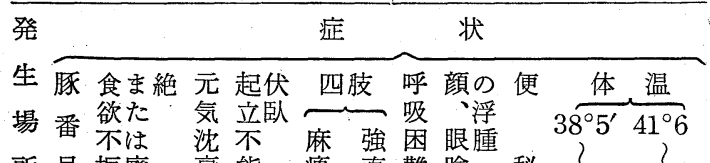

所号振廃衰能痺直難瞼秘 $39^{\circ} 5^{\prime} 41^{\circ} 8^{\prime}$

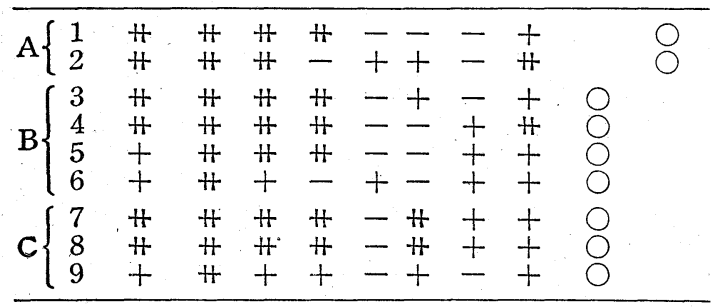

4 頭について病理解剖を実施した。4例とも全身の浮 腫性変化と循環障害が主要変状であった。

\section{7. 病理組織所見}

2 例の藏器について農林省家畜衛生試験場に病理組織 検查を依頼した結果， 1 号豚では胃腸の高度水腫，なら びに肝, 腎, リンパ節などの実質の壊死と局所循環障害 が重要所見としてみとめられ，2号豚では胃粘膜下織の 水腫, 腸粘膜固有層の壞死および水腫, 細小血管の血栓 形成, さらに肝の累状壊死, 円形細胞結節, リンパ節の 広範な壊死, 縢髄の宩状壊死, 中枢神経系の囲管性細胞 集簇などの所見がありトキソプラズマ病との合併と考え
第 5 表 血 液 検 査 成 績

\begin{tabular}{|c|c|c|c|c|c|c|c|c|}
\hline 豚 & 白 & 赤 & \multicolumn{3}{|c|}{ 百 } & \multicolumn{2}{|c|}{ 率 } & \\
\hline 番 & 血 & 血 & 好 好 & 単 & リ球 & 好 & 中 珠 & 求 \\
\hline & 球 & 球 & 塩 酸 & & y & メ夕骨 & 稈状 & 分葉 \\
\hline 号 & 数 & 数 & 球 球 & 球 & パ & 䯣細胞 & 核 & 核 \\
\hline 2 & 100 & $\begin{array}{r}\text { 万 } \\
462\end{array}$ & $\begin{array}{r}\% \\
-2.7\end{array}$ & $\begin{array}{r}\% \\
12.8\end{array}$ & $\begin{array}{r}\% \\
53.4\end{array}$ & $\begin{array}{r}\% \\
2.7\end{array}$ & $\begin{array}{r}\% \\
24.6\end{array}$ & $\begin{array}{r}\% \\
3.8\end{array}$ \\
\hline 4 & 400 & 506 & $\rightarrow 0.4$ & 7.4 & 34.8 & 3.4 & 50.0 & 4.0 \\
\hline
\end{tabular}

られた。

\section{8. 治療方法}

8 例について治療を試みた。浮腫病の病因については まだその本態が判然としていないので治療方法も確立さ れておらず対症療法の域を脱していないが，食欲減退元 気沈衰をみとめて直ちに早期治療を扎をなったものと， サルファ剂およびピリミヂン製剤の投与は多少効果があ ったようである。

\section{あとがき}

ここに述べた病例は病理学的にはトキソプラズマ病を 合併していると認められたが，一般症状には従来報告さ れている豚の浮腫病に類似しているところもある. 本病 は多頭飼育化にともない重要な疾病と思われるので, さ らに病例の検索を積みかされ発生要因, 治療方法などに ついての調查を進めたい. 
ネグボンの非経口投与による犬アカラス症新治療法の研究（第 2 報）

皮内注射時に和けるネグボンの滲透性の観察ならびに投与患大の病理学的検索と 治療効果について

八竹昭夫* 千葉䜌孝**

演者は, 第 82 回日本臨床獣医学会にネグボンを犬ア カラス症に応用するにつき，皮内注射，皮下注射，静脈 注射，塗布洗滌，内服注ういて検討し，玉た本剤が低毒 性とはいらものの有機橉製剤であるだけに，その使用は とくに慎重でなくてはならないといら観点から毒性耐過 試験む行ない，これらを報告してきた。

その結果本剤が犬アカラス症に適用することは臨床上 可能であるという結論から今回はまず臨床的に最も応用 価値のある皮内注射法, 洗滌塗布の 2 法にしぼり，その 用量を決定するためにまずアカラス人工感染犬の患部皮 膚に $2.5 \%$ ネグボン溶液にメチレンブルーを混じ皮内に 注射し 30 ６0 分後に气の周辺を含めた皮膚を切開して 裏側よりまをた断面より本剤の渗透性を調べ $1 \mathrm{~cm}^{2}$ 当り $0.5 \mathrm{cc}$ 必要であることを認めた：そして前回の毒性耐過 試験の結果とも勘案して安全量を $25 \mathrm{mg} / \mathrm{kg}$ という数字 を割出しここの算定法を基礎にして臨床投与試験を行な ったわけである．そしてアカラス症をつぎの 3 期に分類 し，治療効果についてまとめた。

まずI期とは感染初期および比較的炎症を伴なわない 小範囲のもの, II 期とは感染後経過日数の多、比較的小 範囲の炎症を伴なうもの, もしくは感染初期でも高度の 炎症を伴なうもの，III期とは感染後著しく経 過したも の, 肉眼的にも組織の変性を認め得るもの, 祘よび患部 が全身的に及ぶものをこの期衹分類した。また皮内注射 は $5 \%$ ブドウ糖液または生理食塩水で $2.5 \%$ のネグボン 溶液にし $2 \sim 5$ 日間隔で $4 \sim 23$ 回処置を続子併用例では これらの処置の他に毎日 $2.5 \sim 10 \%$ のネグボン溶液を患 部に塗布， 1 週間に $1 \sim 2$ 回 $0.5 \sim 0.1 \%$ 溶液にて洗滌 を行なったものである.

別表のと敊り本症 I 期ではほぼ完全に目的を果した が，II期では治癒率はグンと低下し，期に至っては無 効に近い結果が出ている.

一方病理像について言及すると, アカラス症の感染を

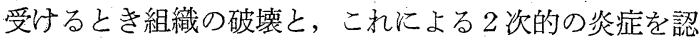
め暫時これが波交してくる。すなわち皮脂腺, 毛囊乞の 他病変が渗透する。これが慢性化するとこれらの部位 の萎縮を起こし，あるものでは皮脂腺が増生する。また 炎症が持続するときには血管炎を伴なら．皮内注射後の 組織像をみると比較的卵扣よび皮款をもっている脱皮前 のものにはネグボンの渗透が困難のようで，卵や被囊幼

* 岐阜県開業 ** 名古屋大学環境医学研究所

日獣会誌 18 (1965)
○皮内注射単独処置群 (22例)

\begin{tabular}{cccccc}
\hline & & 供試例数 & 全治 & 略治(施療中) & 無効 \\
\hline $\mathrm{I}$ & 期 & 7 & 6 & 1 & 0 \\
$\mathrm{II}$ & 期 & 10 & 2 & 2 & 6 \\
$\mathrm{III}$ & 期 & 5 & 0 & 1 & 4 \\
\hline
\end{tabular}

○皮内注射塗布洗滌併用処置群 (34例)

\begin{tabular}{rrrrrr}
\hline I & 期 & 13 & 12 & 0 & 1 \\
II & 期 & 14 & 6 & 2 & 6 \\
III & 期 & 7 & 1 & 1 & 5 \\
\hline
\end{tabular}

○内服単独処置群（対照区）(12例）

\begin{tabular}{ccccccc}
\hline I & 期 & 4 & 0 & $1^{*}$ & 3 \\
II & 期 & 6 & 0 & 0 & 6 \\
III & 期 & 2 & 0 & 0 & 2 \\
\hline
\end{tabular}

* 1 力月後併用処置

虫が根源となって再び本症を惹起するものと思う。また あるものは不顕性で終るものもあるが反復投与の必要性 はこの辺の理由による.

アカラス成虫, 運動蛹の寄生場所は毛囊, 皮脂腺, リン 公節である。立た毛囊内では膿胞状となっている像から これが主役を演じているものと思う。すなわち生活力の

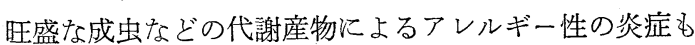
見逃すことができない，乙かし真皮組織内に遊走したも のはこれが膿瘍を形成するが，遊走して真皮内にあるも のはいずれも死滅しているものと思う。

つまり皮膚の寄生深度は皮膚表面の近くから真皮の深 い層汇至るきわめて巾のある寄生を示している.

\section{結 論}

（1）ネグボンを皮内注射する場合 $1 \mathrm{~cm}^{2}$ 当り最小限 $0.5 \mathrm{cc}$ で完全に滲透する.

（2）ネグボンを皮内注射ならびに塗布した場合，これ の単独ならびに併用では初期にのみ著効をみるが期以 上進行したものでは困難である．また対照の内服単独例 では臨床上，病理組織像にも効果を認めることができな かった.

（3）すなわち本症の感染を受けると組織の破壞とこれ による 2 次的炎症, つまり虫体の代謝産物によるアレル ギー性炎と細菌感染の炎症が伴なら，

（4）ゆ元に本症治療にはネグボンなどの抗虫剤と併せ て抗生物質; 抗ヒスタミン剂, 副腎皮質ホルモン剂の併 用療法は不可欠の治療と思う。 
第94回日本臨床獣医学会（四国）期日 : 昭和38年 7 月24日 会場 : 松山市, 井関農機(株)ホール

$$
\begin{aligned}
& \text { ヒドロキシナフトエ酸アルミニウム主成剤応用による子豚の } \\
& \text { 下痢症に対する治療試験について }
\end{aligned}
$$

\section{景浦忠德* 荒川満雄* 渡辺貞昌*}

最近の豚飼育頭数の増加はめざましいものがあり，し か子、飼育形態は逐次集団あるいは多頭化され，それに伴 ない各種伝染性疾病なども多発の傾向にある.

なかでも, 子豚の下痢昰の発生率はかなり高く, 幼弱 な子豚が一度下㾥を㨟こすと, 抵抗力が弱いので, 急速 に衰弱し, 一い死するものも多く, また回復しても所謂 「ひね豚」となり, 発育が著しく括くれるので, 責豚家 にとって経済的損失は極めて大である.

哺乳中ならびに離乳後まもない子豚の下痢症の原因 は, （i ）細菌性のものとしては, 病原性大腸菌による 子豚の下痢, サルモネラによる豚パラチフス, ビブリオ による豚の赤痢, その他，（ii）ウィルス性のものとして は, 最近集団的に多発している伝染性胃腸炎 (T.G.E) その他, エンテロウィルスによるもの,（iii）寄生虾 よるものとしては, ランソン桿虫(ふんかん虫), 大腸バ ランチジウム, コクシジウムなどあり，(iv）母乳のア シドージスによる不良乳の哺乳, ( v ) 栄養障害, 中毒 によるものなどに分類されるが, 細菌性のものもかなり 多い。

今回われわれも「ヒドロキシナフトエ酸アルミニウム 主成剂」を主として, 子豚の下痢症に応用し, 著効を認 めたので，その治療試験の概要を報告する。

\section{1. 試験薬剤和よび方法}

(1) 試験に応用した薬剤

「ヒドロキシナフトエ酸アルミニウム主成荗」で製剤 $1 \mathrm{gr}$ 中に, ヒドロキシナフトエ酸アルミニウム $100 \mathrm{mg}$. ヨードクロロハイドロキシノリン(キノホルム) $100 \mathrm{mg}$ を含有する黄色の顆粒である。

(2) 試験に供用した動物

多頭飼育の行なわれている養豚場の下湴発生群, $\mathrm{K}_{1}$, $\mathrm{K}_{2}, \mathrm{~K}_{3}, \mathrm{~K}_{4}$ 抒よび I の 5 群 40 頭ならびに, 一般農家飼 育の下痢発生群, S, O,T,M, の 4 群 22 頭合計 9 群 62 頭に ついて実施した.

いずれも, 生後 60 日以内のもので, 寄生虫陰性のも のである.

\section{（3）投薬の量および方法}

投薬量は生体重 $\mathrm{kg}$ 当り $0.2 \mathrm{gr}$ を 1 日の標準量とし, 1 日分を 2 回に分け, 少量の飼料に混和し投与した。

\footnotetext{
* 愛媛県卸荘家畜保健衛生所
}

治療中離乳豚は若干減食させ, 哺乳豚は投薬後 $2 \sim 3$ 時間経て授乳させた。

(4) 試験の期間

昭和 38 年 4 月下旬から 6 月上旬まで,

\section{-II 治療試験成績}

第 1 表に示すごとく, 6 養豚場(No. 1,2,3,4, 5, 6)の 9 群 $\left(\mathrm{S}, \mathrm{O}, \mathrm{K}_{1}, \mathrm{~K}_{2}, \mathrm{~K}_{3}, \mathrm{~K}_{4}, \mathrm{~T}, \mathrm{M}, \mathrm{I}\right)$ の 62 頭について, 本剤を応用したが，S,O 群はいずれも過食, 盗食などの 飼養管理の失宜による食䬣性のもので, 重い下㾰をおこ していたが，投薬後 1 日で軟便，2 日で完全に治瘾して いる.

つぎに同一養豚場の $\mathrm{K}_{1}, \mathrm{~K}_{2}, \mathrm{~K}_{3}, \mathrm{~K}_{4}$ の 4 群は, しずれ も細菌性によるもので, 投薬前の下痢便から, 病原性の 大腸菌を検出して打り, なかでも， $\mathrm{K}_{1}, \mathrm{~K}_{2}$ 群は $2 \sim 3$ 日 の投薬で完全あるいは略治療したが, $\mathrm{K}_{2}, \mathrm{~K}_{4}$ においては 一旦全頭治癒したかと思われたが，1両日中に， 6 頭再 び下㾥を执こし，再投薬により 4 頭は治瘾したが， 2 頭 は悪化し治癒せずへい死した。

また T, M, I の 3 群は，いずれも管理失宜によるもの で, 離乳時の餌付失敗, 母乳の異常, 給与飼料の変質な ど, 食餌性の下㾥であったが投薬後 2 日で完全治療して いる.

な㧍，サルファ剂および抗生物質製剤で施療効果のな かった事例に対し, 本剂を応用し, 効果を認め, また寄 生虫陽性の下痢症のもの 7 頭を対照的に 2 日間投薬した が，一時的に症状が軽快するも再度下痢を発し，寄生虫 による下痢症には効果は認められなかった。

\section{3. 結論および考察}

(1) 本剂を 9 群 62 頭の下㾥発生例飞応用したとこ ろ, 7 群 44 頭の治痖率は 100\%であったが， 2 群18頭 は治癒率 $66.6 \%$ で再投薬により，88.8\%となり，ほと んぞ治痖あるいは軽快しており, 全体の最終治瘾率は $96.8 \%$ で著効を認めた.

な打原因が飼養管理の失宜からの食餌性のみならず, 病原性細菌によるものに対しても広範团に効果を認め た。

（2）寄生虫性の子のについては，本剤投薬後一時下痢 症状軽快するも, 再度下痢を叔こし効果は認められなか 
第 1 表 治 療成 續

\begin{tabular}{|c|c|c|c|c|c|c|c|c|c|c|c|c|c|c|}
\hline No. & 群 & & 性 & $\begin{array}{l}\text { 日 } \\
\text { 令 }\end{array}$ & $\begin{array}{l}\text { 頭 } \\
\text { 数 }\end{array}$ & 投薬前の症状 & $\begin{array}{l}\text { 下痢の } \\
\text { 原因 }\end{array}$ & 投薬月日 & $\begin{array}{l}\text { 投体 } \\
\text { 薬重 } \\
\text { 時 }\end{array}$ & $\begin{array}{l}\text { 投 } \\
\text { 薬 } \\
\text { 量 }\end{array}$ & $\begin{array}{l}\text { 投数 } \\
\text { 薬 } \\
\text { 回 }\end{array}$ & $\begin{array}{l}\text { 投薬の効果判定. } \\
\text { 抢よび経過 }\end{array}$ & $\begin{array}{l}\text { 治数 } \\
\text { 癒 } \\
\text { 日 }\end{array}$ & $\begin{array}{l}\text { 再 } \\
\text { 発 }\end{array}$ \\
\hline 1 & & $\mathrm{~S}$ & $\begin{array}{l}\text { is } 2 \\
\text { ㅇ } 2\end{array}$ & 32 & 4 & $\begin{array}{l}3 \text { 日前より下痢症状 } \\
\text { あり投薬前は鴧利 } \\
\text { 便・栄養やや不良 }\end{array}$ & $\begin{array}{l}\text { 食餌性 } \\
\text { (過食) }\end{array}$ & 63.4 .26 & $\begin{array}{r}(\mathrm{kg}) \\
7.2\end{array}$ & & 4 & $\begin{array}{l}1 \text { 日の投薬で軟便 } \\
2 \text { 日で完全治癒 }\end{array}$ & 2 & - \\
\hline \multirow[t]{3}{*}{2} & & $\mathrm{O}$ & $\begin{array}{ll}\hat{0} & 0 \\
\text { o } & 2\end{array}$ & 20 & 2 & $\begin{array}{l}2 \text { 日前より泥状軟便 } \\
\text { 投薬日は下痢便 }\end{array}$ & $\begin{array}{l}\text { 食餌性 } \\
\text { (盗食) }\end{array}$ & 63.5 .14 & 5.5 & 1.2 & 3 & 1.5日略, 完全治癋 & 1.5 & 一 \\
\hline & & $\mathrm{K}_{1}$ & $\begin{array}{ll}\text { o } & 3 \\
\text { o } & 6\end{array}$ & 27 & 9 & $\begin{array}{l}3 \text { 日前より下痢症状 } \\
\text { あり, 施療効果なし } \\
\text { 症状悪化 }\end{array}$ & 細菌性 & 63.5 .20 & 6.8 & 1.4 & 5 & $\begin{array}{c}2 \text { 日の投薬で略治 } \\
\text { 癋, } 2.5 \text { で完全治癒 }\end{array}$ & 2.5 & - \\
\hline & & $\mathrm{K}_{2}$ & $\begin{array}{ll}\text { o } & 4 \\
\text { 우 } 5\end{array}$ & 22 & 9 & $\begin{array}{l}3 \text { 日前より慢性化し } \\
\text { た白痢便. 投薬前は } \\
\text { 水椂便 }\end{array}$ & 細菌性 & 63.5 .20 & 5.8 & 1.2 & 5 & $\begin{array}{l}2.5 \text { 日の投薬で略 } \\
\text { 治癒 }\end{array}$ & 3.0 & 一 \\
\hline \multirow[t]{2}{*}{3} & & $\mathrm{~K}_{3}$ & $\begin{array}{ll}\hat{0} & 4 \\
\text { oे } & 6\end{array}$ & 22 & 10 & $\begin{array}{l}7 \text { 日位前より慢性化 } \\
\text { の白劁便, 投薬前は } \\
\text { 水様便 }\end{array}$ & 細菌性 & 63.5 .24 & 5.7 & 1.2 & 6 & $\begin{array}{l}3 \text { 日連投により固 } \\
\text { 形便となり治癒す } \\
\text { るも1日後再 } \\
\text { 痢. 再投薬により } \\
4 \text { 頭治㾙 }\end{array}$ & 3.0 & + \\
\hline & & $\mathrm{K}_{4}$ & $\begin{array}{ll}1 & 2 \\
0 & \\
\text { 우 } & 6\end{array}$ & 18 & 8 & $\begin{array}{l}5 \text { 日前より下痢症状 } \\
\text { やや慢性化, 発育不 } \\
\text { 良 }\end{array}$ & 細菌性 & 63.5 .28 & 4.0 & 0.8 & 7 & $\begin{array}{l}3.5 \text { 日の投薬でる } \\
\text { 応固形便となる } \\
1 \text { 日後下痢, } 2 \text { 頭 } \\
\text { は治癒せず }\end{array}$ & 3.5 & + へ頭 \\
\hline 4 & & $\mathrm{~T}$ & $\begin{array}{ll}1 & 3 \\
\text { o } & 3 \\
\text { ㅇ } & 3\end{array}$ & 40 & 6 & $\begin{array}{l}2 \text { 日前より余りはゲ } \\
\text { しない下痾症状 }\end{array}$ & $\left.\begin{array}{l}\text { 食䬲性 } \\
\text { 離乳の } \\
\text { 失敗 }\end{array}\right)$ & 63.5 .29 & 8.2 & 1.7 & 3 & $\begin{array}{c}1 \text { 日の投薬で略治 } \\
\text { 癒, } 1.5 \text { 日完全治瘭 }\end{array}$ & 1.5 & - \\
\hline 5 & & M & $\begin{array}{l}\text { ô } \\
\text { ㅇ }\end{array}$ & 10 & 10 & $\begin{array}{l}4 \text { 日前より下痢便， } \\
\text { 施療するも效果なく } \\
\text { 症悪化 }\end{array}$ & $\left.\begin{array}{l}\text { 食䭅性 } \\
\text { (乳の } \\
\text { 異常 }\end{array}\right)$ & 63.6. 1 & 2.5 & 0.5 & 4 & $\begin{array}{l}1 \text { 日の投薬で軟便 } \\
\text { となり, 略治癒. } \\
2 \text { 日完全治㾙 }\end{array}$ & 2.0 & 一. \\
\hline 6 & & $\mathrm{I}$ & $\begin{array}{ll}\hat{\circ} & 3 \\
\circ & 1\end{array}$ & 55 & & $\begin{array}{l}3 \text { 日前より，余りは } \\
\text { げしくない下痢症状( } \\
\text { 施療効果なし }\end{array}$ & $\begin{array}{l}\text { 食慨性 } \\
\text { (給与飼料 } \\
\text { の変質 }\end{array}$ & $63.6 \cdot 5$ & 14.4 & 3.0 & 3 & $\begin{array}{l}1 \text { 日の投薬で略治 } \\
\text { 摩, } 1.5 \text { 日完全治癒 }\end{array}$ & 1.5 & - \\
\hline & 計 & & $\begin{array}{l}\text { o } 25 \\
\text { ᄋ. } 37\end{array}$ & $\begin{array}{l}\text { 平土 } \\
24 .\end{array}$ & 762 & & & ${ }_{6 .}^{4.26}$ & 平均 & 坢均 & $\begin{array}{r}\text { 平均 } \\
4.8\end{array}$ & & $\begin{array}{l}\text { 平均 } \\
2.47\end{array}$ & \\
\hline
\end{tabular}

第 2 表 寄生虫陽性豚に対する治療効果

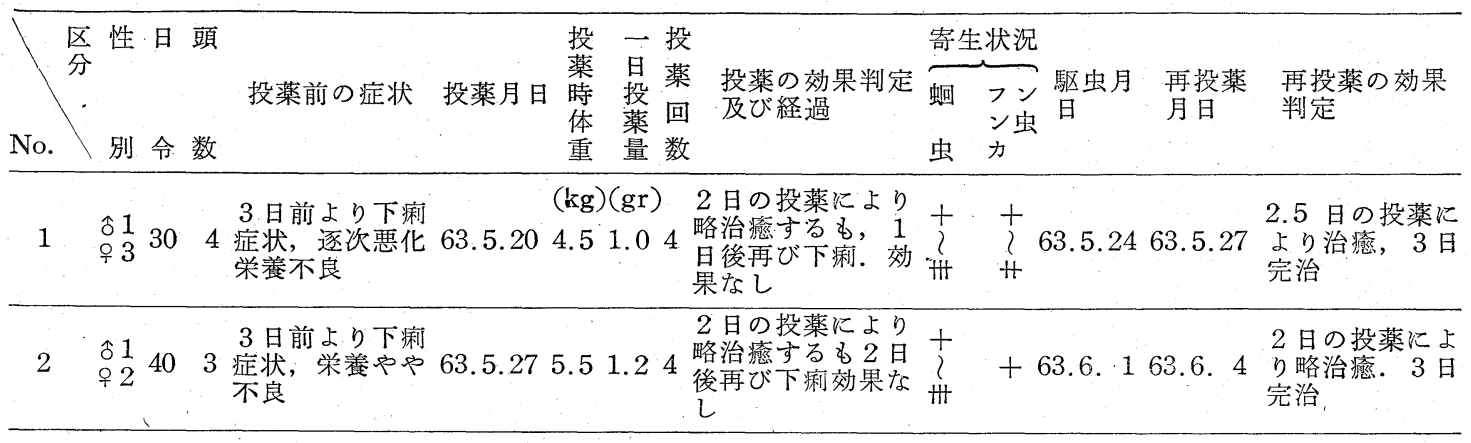

第 3 表 投薬回数別治癒率

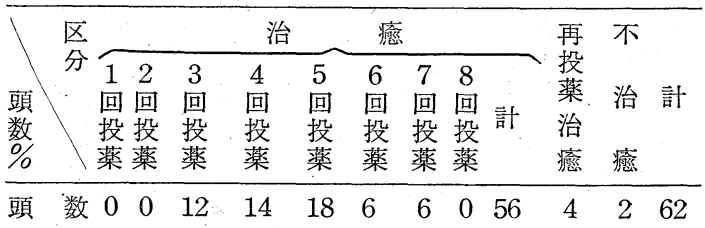

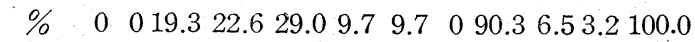

ったので，必らず糞便検査を行ない寄生虫によるものは

日獣会誌 18 (1965)
駆虫を行ない後投薬すること．

(3) 治癒日数については, 最も早いもので1.5 日 ( 3 回投薬)，また最も预そいもので 3.5 日（7 回投薬）平 均 $2 \sim 2.5$ 日程度で, 治癒の目的を達しているが, 哺乳 中あるいは離乳直後の子豚の下痢は, 早期発見, 早期治 療が緊要である.

（4）サルファ剂および抗生物質製剤で施療効果のなか った事例に，本剤の効果のあったことは注目すべきであ ると思われる。 
（5）不治療のため，へい死した 2 頭は，生時体重も少 なく，䝷血性虚弱豚で投薬により一時治瘾したが，すぐ 再発しへい死した。

解剖の結果, 腸粘膜は強度のカタール性炎症をおこし て叔り, 寄生虫以認められなかった。

(6) 強度の母乳異常之思われるものについては, 哺乳 中であれば再三発症するから, 離乳し投薬すること.

(7) 薬剂の副作用は全く認められなかった。
以上のごとく「ヒドロキシナフトエ酸アルミニウム主 成剂」は細菌性下痢症沶よび飼着管理失宜によっておき た子豚の下痢症に対しては著効を認めたが，本症による 農家経済に及ぼす影響は大であるので，今後も多発を予 想される下痢症だけに，予防的見地から生後 10 日頃か ら離乳するまで，また子豚として体力の完成するまで, 1 週間隔程度で本剤を投与すれば下痢症は減少し, 養豚 経営は安定するものと思考される。

第95回日本臨床獣医学会（近畿）期日：昭和38年 8 月 18 日 会場 : 神戸市, 兵庫県農業会館

\section{豚の浮腫病様疾患とその予防について}

\section{田端清寿* 森内俊一* 玉本昌秀*}

1962年 5 月頃から伊賀地方の一部に豚の浮腫病様疾患 が発生して抢り1963年 6 月までに 78 頭の発生をみた. そのうち 5 例を農林省家畜衛生試験場に送り病性の鑑定 を行なったところ病理組織学的所見から浮腫病と診断さ れ，また病原性大腸菌 0 139 が分離同定された。

\section{1. 発生 状 況}

1）地区別発生頭数（表 1）2）月別発生頭数(表 2) 発生地域は 4 地区に限られており地区別の発生率ならび に季節に上る発生の多少についての有意差はみられなか ったがC V V 注射後の発生は注射前の発生上りも多く又 られた．3）病豚の大きさは生後38～80日体重13～28kg 哺乳日数 $30 \sim 67$ 日のもので哺乳期間中のものと生後 80 日以降のものからの発生はなくまた同腹産子の中で発育 旺盛なものから $2 \sim 3$ 頭が続いて発生する傾向が強い.

表 1 地区別発生頭数

\begin{tabular}{|c|c|c|c|c|c|}
\hline 地区別 & $\begin{array}{l}\text { 飼育 } \\
\text { 頭数 }\end{array}$ & $\begin{array}{l}\text { 期間中子豚 } \\
\text { 生産頭数 }\end{array}$ & 発生 & $\begin{array}{l}\text { 登生 } \\
\text { 頭数 }\end{array}$ & 発 生 率 \\
\hline 阿山村 & 1,500 & 3,900 & 13 & 47 & $1.205 \%$ \\
\hline 大山田村 & 400 & 1,114 & 4 & 13 & 1.16 \\
\hline 上野市 & 600 & 1,312 & 5 & 18 & 1.37 \\
\hline 計 & 2,500 & 6,326 & 22 & 78 & 平均 1.23 \\
\hline
\end{tabular}

4) 給与飼料の状況, 本病発生の 22 農家について行な った調查結果は完全配合飼料と称するブーレット B, C, 子豚配合を使用するものが大部分でしかも不断給慨ある いは1日 3 回に十分飽食させており，むしろ過食状態の ものに多く発生している. また緑慨の給与量は少なくカ ルシウム等微量栄養素は給与されていない，5）離乳と

表 3 離乳と C V V 注射と本病の関係

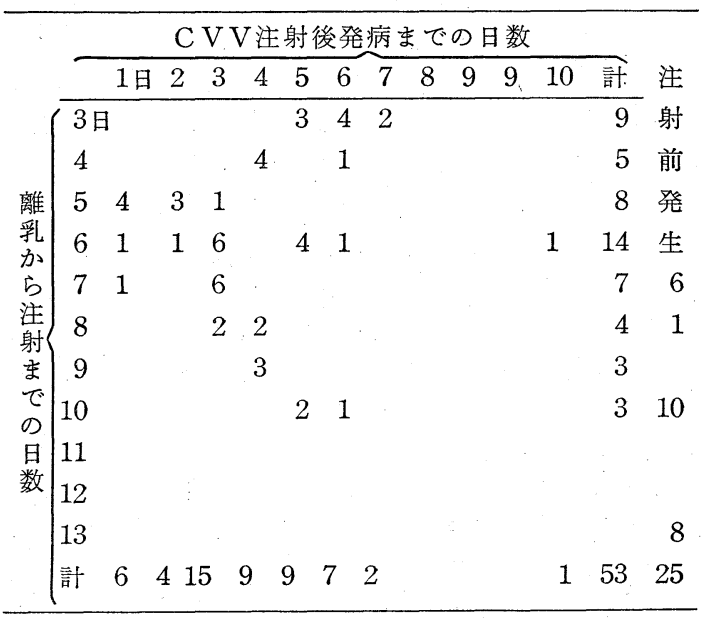

表 2 月 別 発 生 頭 数

\begin{tabular}{l} 
月 \\
\hline 別
\end{tabular}

* 三重県伊賀家畜保健衛生所 
CVV注射と本病の関連（表 3) 78例中 53 例 $(68 \%)$ がCVV注射後に発生して赤り 25 例 (32\%) が注射前 の発生であったがその原因として考兄られることは，昭 和 37 年は県内の他の地域で豚コレラが発生して和り急 速に免疫を与兄る必要から離乳直後のものにもやむを得 ずCVV注射を行なったものからの発生が多かったもの であって離乳後 10 日以上経過して予防注射を行なった ものからは発生していないまた注射前に発生したグル 一プについてみると離乳後 13 日までに発生しているこ とから離乳後 2 週間以内は本病の最も発生しやすい時期 といえる。

\section{II 症状ならびと治療}

1）臨床症状(表 4): 主なる所見は元気食欲の急減と ともに歩様異常がみられ続いて後銵、ヒ眼瞼腫脹が高度 にみられ呼吸困難に执ちいって死亡するものが多く，下

表 4 臨床症状

\begin{tabular}{|c|c|c|c|c|c|}
\hline 所 見 & + & \# & 曲 & 計 & $\%$ \\
\hline 「眼 & 34 & 25 & & 59 & 75.0 \\
\hline 浮腫 \{顔 & 25 & 1 & & 26 & 33.3 \\
\hline |下顎, 下腹 & 15 & & & 15 & 19.2 \\
\hline 食䶼減, 全 廃 & 4 & 16 & 55 & 75 & 96.1 \\
\hline 歩 様 異 常 マ ヒ & 17 & 34 & 27 & 78 & 100.0 \\
\hline 結 膜 充 血 & 30 & & & 30 & 38.0 \\
\hline 痢 & 19 & 5 & & 24 & 30.7 \\
\hline 熱 $\left(40^{\circ} \mathrm{C}\right)$ & 12 & & & 12 & 15.3 \\
\hline 嘔 吐 & 3 & & & 3 & 3.8 \\
\hline
\end{tabular}

痢発熱を伴なったものは少なかった，2）経過ならびに 転帰：いずれも急性経過をたどり,28例が 5 時間以内, 26 例が 10 時間以内, 16 例が 15 時間以内に死亡し全例が 24 時間以内に死亡し 4 例が回復した. 3）治療成績 : 28 頭 を治療し 4 頭が回復したが一般には急性なため手当をす る余ゆうのないのが現状で, 比較的軽症のもので経過の 長いもののみが回復している。治療法はサルファ剂の内 服高単位ペニシリン, ビタミン剂, 強心利尿剂等による 対症療法である.4) 解剖所見(表 5)：28例について行 表 5 剖検 所見 (28例)

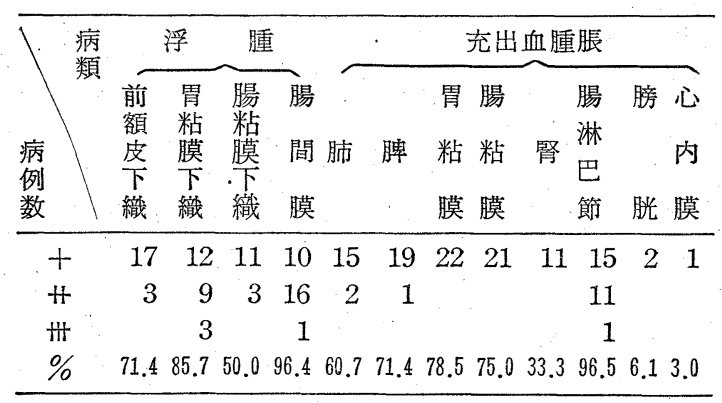

日獣会誌 18 (1965)
なった剖検所見は前額部皮下織, 胃粘膜下織, 腸間膜の 水腫が著明なほか腸りンパ節の充血腫脹が高度にみられ た. 5) 病理組織学的所見 (表 6)

表 6 病理組織学的所見

\begin{tabular}{|c|c|}
\hline 肝 & 中心性うっ血中心性肝細胞萎縮 \\
\hline 脾 & 軽度のうっ血または出血とR E S 活性化 \\
\hline 腎 & 軽度のうっ血と充出血 \\
\hline 肺 & 水腫 \\
\hline 胃 & と軽度の出血 \\
\hline 脳 & 軽度のうっ血と限局性の \\
\hline リン & 節 細胞稀薄質の強いらっ血, 軽度の R E S 活性化 \\
\hline 判穴 & $\begin{array}{l}\text { 胃の幽門腺部, 粘膜下織の極めて強い浮腫と出血 } \\
\text { 諸臟器にみられる循環障害から浮腫病と診断され } \\
\text { る. }\end{array}$ \\
\hline
\end{tabular}

\section{III 予 防 対策}

急性重度の経過をたどり治療効果のない本病に対し適 確な予防処置のない今日ではこれが発生の絶無をきする ことは困難ではあるが 37 年の調査結果基いてわれ われはとくにつぎの予防手段を構じている.1. 子豚 の C V V 注射時期の徹底: 豚コレラ蔓延下に和忷る防疫 の必要性から離乳直後のものにもやむを得ず予防注射を 実施したものに発生が多かったことから，子豚のCVV 注射時期は離乳後 2 週間以上経過してから実施すること を厳守し. また注射後 2 週間以降に出荷販売を励行し た. その結果 37 年中の発生数の内 $73 \%$ が C V V注射 後の発生であったものが本年は $50 \%$ に減少し注射前後 の発生率の差はみられなくなった. 2. フラゾリドンの 給与: 浮腫病の発生に病原性大腸菌O-139 が重要な役割 を演じているとすれば投薬の方法が適切であれば発生を 予防できるほか予後をよくするとかの効果が期待できる ほか, 細菌性下痢を防ぎ発育を均一良好たらしめる利点 も望めるので農家が最も入手しやすい「NF-180」を試用 した結果極めて有効であり子豚が強健に育つことがわか った(表 7). 3. 飼羑管理の改善 4. 豚舎の消毒励行

表 7 フラゾリドンの給与

\begin{tabular}{ll}
\hline 使用薬品 & $\mathrm{NF}-180$ \\
使 用 法 & $\begin{array}{l}\text { 餌付期から子豚出荷まで50日間 } \\
\text { 料混与 }\end{array}$
\end{tabular}
使用効果 $\begin{gathered}\text { 頭 } \\ \text { 数 }\end{gathered}$ 使用期間
使用量\%

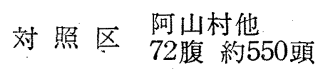
発生16頭 


\section{IV 考察}

(1) 東北北海道地方のみでなく三重県にも本病の発生 が確認されたことからその他の地域にも発生の可能性が 考えられる. (2) 同腹産児の中でとくに発育のよいもの から好発する傾向が強くこれは濃厚飼料の過食による胃 腸障害と微量栄養素の欠乏が素因であろうと考えられ
る.（3）本病の原因については病原性大腸菌O-139によ るアレルギー説, 副腎皮質ホルモン障害, 栄養障害説等 で定説はないがこれらの諸因に，さらに離乳による体力 の減退, 飼料の急変, 離乳直後の $\mathrm{CV} \mathrm{V}$ 注射等多くのス トレスの交さくによって起こるものと思われるのですで にのべたごとき予防対策を励行することによってかなり の予防効果が期待できる.

\section{犬の試作盲腸薬剤送入器の紹介}

\section{岸上 正 義*}

犬において鞭虫の主な寄生部位は盲腸および結腸の上 部である点から該部に確実な送薬が可能であれば駆虫薬 の内服や注射に比して最も合理的な駆虫方法といえる.

犬鞭虫駆除の目的のためゴム製カテーテルを肍門より 挿入し，これを盲腸部に送る方法は宮本により創案され 高岡その他多くの人々によって追試されている.

しかしながらカテーテルの経肛的插入は結腸の解剖学 的構造からその手技には熟練を要し，横行結腸部で腸穿 孔を起こす危惧のあること，および盲腸内に䔬塊を充填 しているため注入した薬物またはとの揮発物が目的とす る鞭虫の虫体に接触するか否かの確実性が疑われるこ と, の 2 つ難点が残されていると私は考光，これらを 打開するためゴム製カテーテルに $2 つ の$ 構想に基いて加 工を施し，これをX線による撮影，および開腹によって その効果を証明し得たので本器を盲腸内薬凧送入器と名 付けここに紹介する。

本器の構造を紹介するに先立ち, 盲腸および結腸の解 剖学的形態を検討すれば，まず盲腸は腸間膜根を中心と して短かい腸間膜の存在によって可動範囲が限定され， 結腸および直腸は約体長に等しい長さで大きく余裕をも

第 I 図 盲腸可動範囲とカテーテルの進入方向

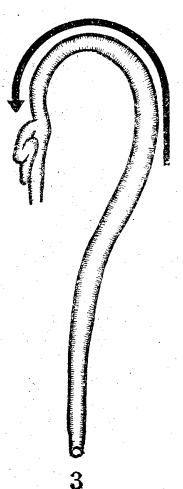

3

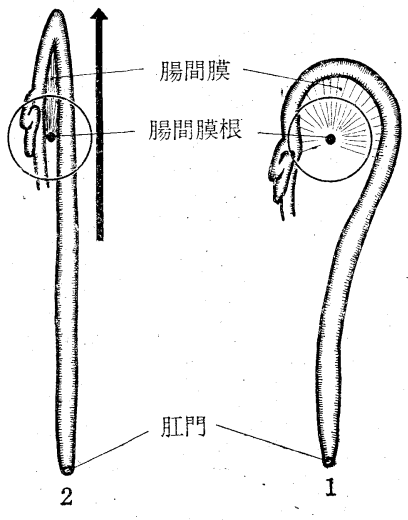

* 大阪南開業
って迂迴している(第 I 図・1 ). そこでカテーテルを体 の正中線の方向に進入する場合, 結腸は腸間膜根と肛門 を2つの基点としてカテーテルの尖端によって腹腔前部 にまで押延ばされ，横行結腸はV字型に屈折し，ために カテーテルの進入はくい止められるのが普通である(同・ 2 ). これをな就強力に押進めれば腸呀孔の結果ををね く場合もあり, 理想的なカテーテルの進入方向は結腸の 迂名に従って進むことにある（同・3）.

第 1 の構想としてこの進入方向を可能にするためカテ ーテルの尖端にステンレスワイヤーを繋りつけ，そのワ イヤーを別の細いゴム管に内蔵し主管に固着させカテー テルの手基でワイヤーを引けばカテーテルの先が屈曲す るごとく装置した(第II図)。なおワイヤーの率引を容易 にするため銃の引金に似た金具を設備し，体長の約半分 の挿入が終った頃にこの引金を引くことによって結腸は 迂迴し，カテーテルは途中で停止することなく進入する ことができる。

第II図 カテーテルの屈伸運動の原理
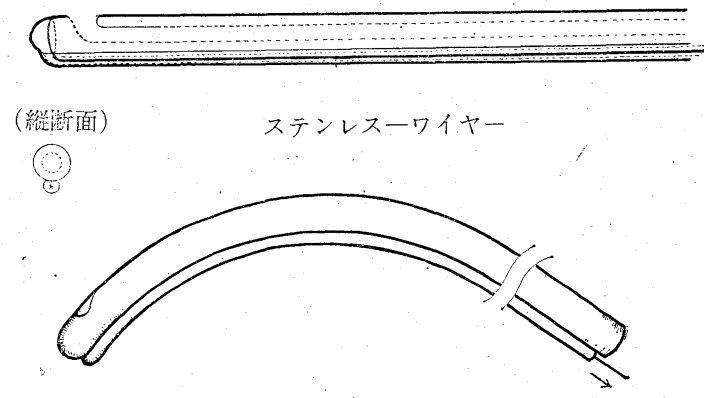

第 2 の構想としてカテーテルの尖端より少しく下った ところに気管チューブに用いられるカフの原理を応用し ゴム製指サックを填込み, その両端をカテーテルに絹付 けして閉鎖し，これに送風用の細いゴム管を主管に沿わ せて気室内に開口させ，基部より空気を送れば気室が膨 脹するように装置した(第而図). 上行結腸は人工的に閉 塞を起こし, 腸管の前後の流通は遮断される. しかも回 盲孔の存在によって内容物の回腸への逆流は防がれてい 
第且図人工閉塞の原理

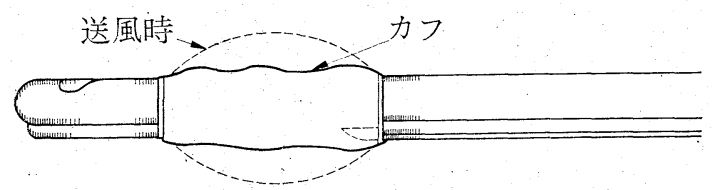

（縦断面）

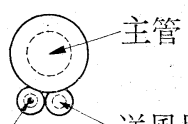

ステンレスワイ送風用管

るため人工閉塞を施した後に主管より液体を送れば何処 へる漏れることなく盲腸内に流入し盲腸は大きく膨満す る(第IV図)：また常水の送入と排出を繰返すことによっ て盲腸内の粪便は洗い出され, 目的とする薬㓮を盲腸尖
第 $\mathrm{IV}$ 図。人工栓塞と強制送液による盲腸の膨隆 (断面・模型図)

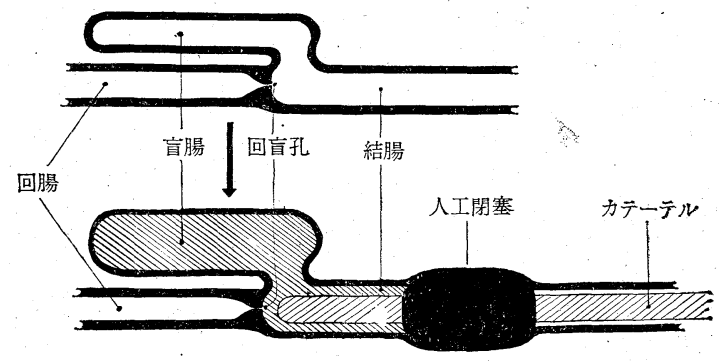

端まで送り込むことができる，その上一定時間薬物を作 用させたのちそれを洗い去ることも可能である.

今回はその器械の紹介にとどめ, 駆虫については今後 有機燐剤, フタロフィン, 沃化ジチアザニン, その他の 水溶液を用いて実験を重ねをの結果を報告したいと思 う.

第96回日本臨床獣医学会 (北海道) 期日 : 昭和 38 年 9 月 7 日 会場 : 岩見沢市, 市民会館

北海道名寄地方に招ける乳牛繁殖性向上と飼料自給度に関する考察

——畑作地帯と水田地带との比較-

浜野健治* 池田 孝* 覚張和夫* 湯浅幹雄* 矢野多郎* 田村良明* 福島貞彦*

[日獣会誌, $\cdot 17$ 巻 6 号掲載〕— $*$ 雪印乳業名寄工場

第97回日本臨床獣医学会 (大阪・小動物) 期日 : 昭和 38 年 9 月 22 日”会場 : 大阪市, 相愛学園講堂

犬の子宮蓄膿症の発生機序に関する考察

第 I 報 発症状沉の統計的観察

佐 藤 啓一* V.R.C会員25名

犬に和活る子宮蓄膿症の発症は年々増加の傾向にあ り, 現今ではわれわ机小動物臨床家にとって重要な疾病 の1つとなった、けれぞもその発生機序に関しては種々 の発表がなされているがな和不可解な点が残されてい る. そこでその解明の一助として多くの臨床家が協力し て患犬例を集め, 光れを集計して観察することは大いに 意義があると思う。

われわれは関西一円, 中国, 九州の広範囲に亘って開 業している関係上観察汇当って地域的な偏見がある程度 是正し得るものと思われる.

この集計で観察した患犬の総頭数は 604 頭であった. その概要はつぎのごとくである。

1. 発症犬の症状（第1 表)

病名決定時, 食欲不振および廃絶 $84 \%$, 嘔吐 $84 \%$, 䝷血 $81 \%$, 腹囲膨湍 $81 \%$, 膿漏 $78 \%$, 脱水 $49 \%$ がと

* 兵庫県開業

日獣会誌・18 (1665)
第 1 表発症犬の症状（病名決定時）

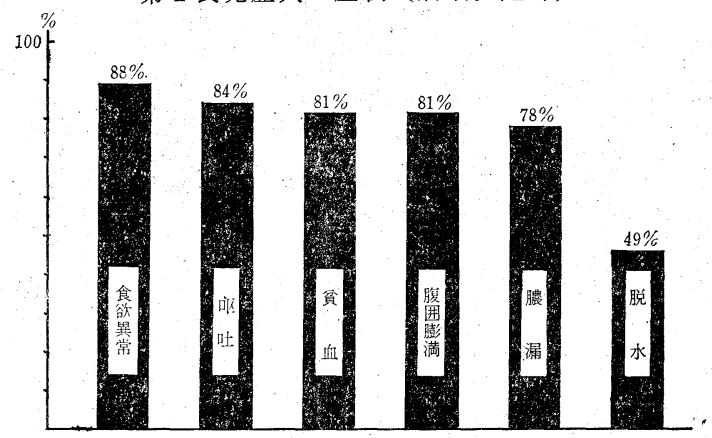

れぞれ認められ，活とんどの例に発情時に似た陰唇の肥 大が認められた。

\section{2. 発症犬の犬種別観察（第2 表）}

全例中スピッツが $45 \%$ で圧倒的に多く, 雑種 $24 \%$, 秋由大 $5 \%$ で以下は犬種別に大差はなかった。スピッッ 
第 2 表 発症犬の犬種別観察

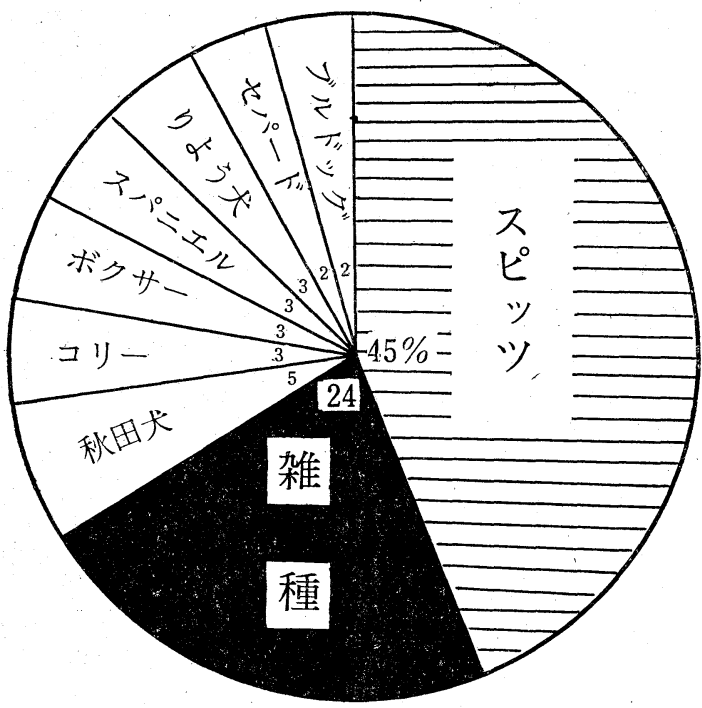

種は現在飼育されている頭数も多いとは思らが示された 数字は興味深いものがある.

\section{3. 発症犬と年令の関係（第 3 表）}

最高は 5 才の $19 \%$ ，つぎに 6 才， 7 才の $18 \%$ ，つい で 4 才の $13 \% ， 8$ 才の $11 \%$ でグラフでは抛物線が画か れている。

第 3 表，発症と年令の関係

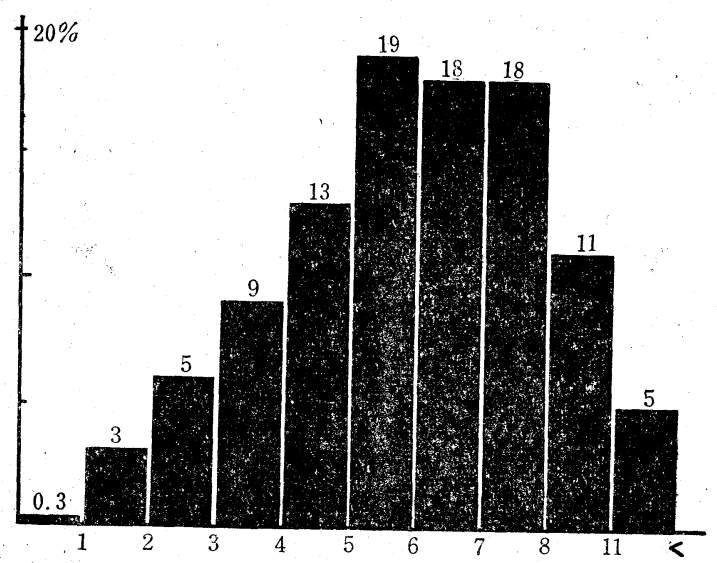

4. 発症当時の栄養状態 (第 4 表)

過肥の状態にあるものが $51 \%$ ，栄養中等のもの $36 \%$, 栄養不良のもの $13 \%$ で, 発症は必ずしも栄養の低下が

原因を作らないことが察知できる.

\section{5. 発症犬の生活環境 (第 5 表)}

生活環境に関しても上項と同様で，過良のもの $48 \%$ ， 比較的良好のもの $45 \%$ ，不良のもの $12 \%$ で一般に運動 不足, 美食, 室内飼育犬洺い傾向があった。

6. 発情から夕を発症時期 (第 6 表)
第 4 表 発症当時の栄養状態

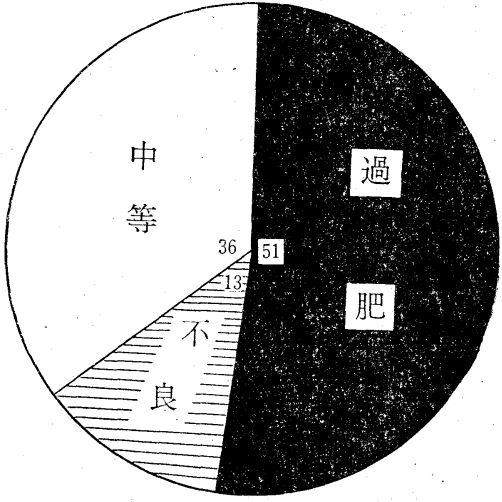

第 5 表 発症犬の生活環境

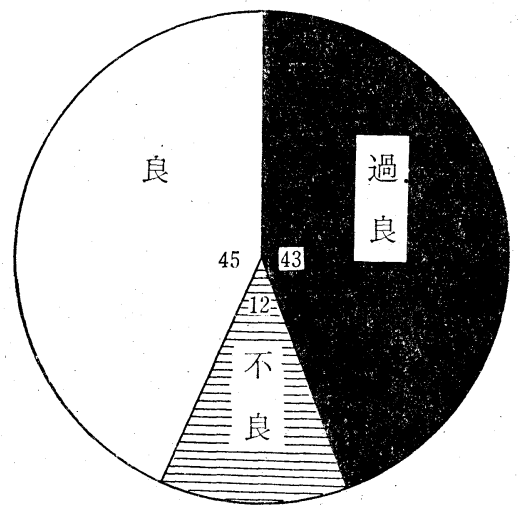

第 6 表 発情から見た発症時期

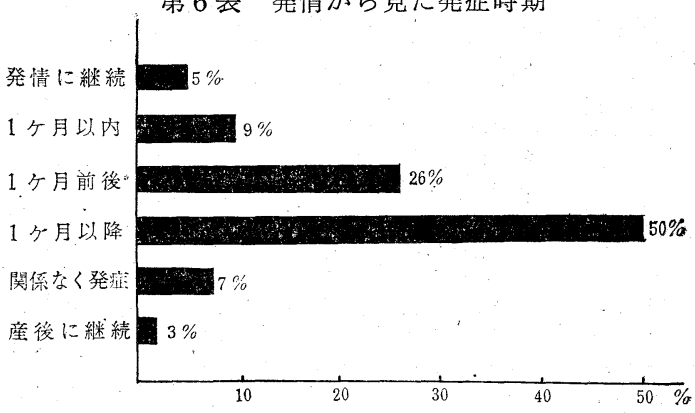

第 7 表 蕃殖と発症との関係

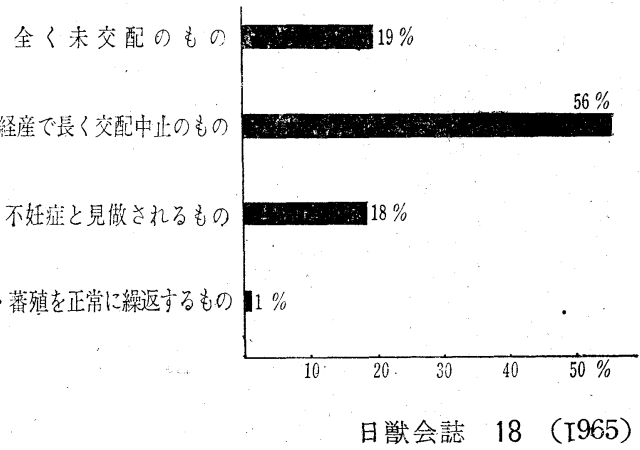


発情後 1 カ月前後または以降を中心として $76 \%$ が症 状を発現している，これは直接の原因と考えられる細菌 の感染が発情時, とくに子宮頸の開緩によって成立する のではないかといら推察がなし得る。

\section{7. 蕃殖と発情との関係（第 7 表）}

経産犬で長く交配を中止しているすのに最も多く56\% を示している. 発情, 蕃殖を正常に繰返したものに発症 が極めて少ない点はとくに注目すべき事項である。また 卵巣摘出手術を行なっている犬での発症は $1.1 \%$ にすぎ なかったことは意外であり，一部の報告と合致しない点 である.

\section{8. 発症犬の転帰（第 8 表）}

発症犬の $80 \%$ は子宮全摘手術に上り治瘾している. 一部に内科的治療，子宮洗涤などによって回復してい
第 8 表 発症 犬の転㷌

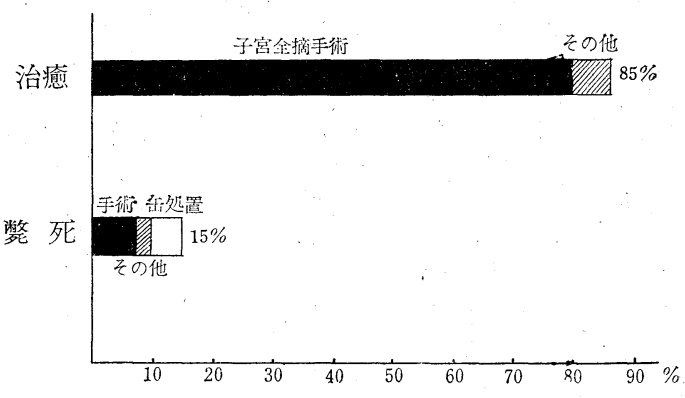

る.

子宮内容物の細菌学的同定拈よび卵栄の病理学的変状 などについては目下検索中である.

第98回日本臨床獣医学会 (東北) 期日 : 昭和 38 年 9 月 27 日 会場 : 福島市, 歯科医師会館

$$
\text { 牛のピロプラズマ病に対する輸血療法について }
$$

\section{村上大蔵* 安田純夫* 藤井義雄* 及川誠一林 滝本喜男** 千葉春雄*** 及川幹夫****}

現在，輸血は人医臨床の凡ゆる分野において重要なる 治療法であり, その適応症に対してはなんら躊躇するこ となく直ちに実施され，極めて効果的かつ安全に行なわ れている. しかるに獣医臨床とくに牛の治療上輸血は極 めて必要なるにかかわらず, その応用は極めて少ない。 私どもは昭和 37 年度以降, 岩手県種山放牧地に発生し た牛のピロプラズマ病に対し輸血療法を行なっているの で, その大要を報告する.

\section{供試牛和よび輸血方法}

供血牛：健康と認められた年令 3 才，体重200 $281 \mathrm{~kg}$ の短角種 7 頭（昭和 37 年 3 頭, 昭和 38 年 4 頭) であ る.

受血牛: 発熱, 貧血を伴なった中等度ないし重度のピ ロプラズマ病牛で, その年令は平均 22.4 カ月, 平均体 重 $282 \mathrm{~kg}$ のホルスタイン種および短角種 45 頭である. これらの病牛に対しては原虫殺隇剤の投与とともに輸血 を行なった。

なお 45 頭中 26 頭は輸血歷を有するものであった。

輸血の方法: 輸血に際しては主交叉試験法および全 血法により，供血牛と受血牛との血液の適合性を検查し た. 抗㠜血鼡としてのクェン酸ソーダは, 血液 $100 \mathrm{cc}$ に 対し $10 \%$ 液 $4 \mathrm{cc}$ 割合に用いた．採血および輸血器具 は輸血用連続注射器, あるいはイルリガートルを用い た. 輸血速度は 1 分間に平均 $35 \mathrm{cc}$ の割合であった。

* 岩手大学農学部 ** 岩手県種山牧昜事務所

*** 岩手県住田家畜保健衛生所 **** 岩手県江刺 家畜保健衛生所

日獣会誌 18 (1965)

\section{実 験 成 績}

1. 昭和 $37 \sim 38$ 年度に括斿る岩手県種山放牧地の輸 血成績

種山放牧地では, 昭和 37 年度 21 頭, 38 年度 24 頭 のピロ羅患牛に輸血を行なった．輸血回数は 1 頭につき 最少 1 回, 最多 8 回平均 2.6 回で, これを頭数別にみる と 1 回, 19 頭, 2 回 8 頭, 3 回 7 頭, 4 回 2 頭, 5 回 3 頭, 6 回 3 頭, 7 回 2 頭, 8 回 1 頭である. 輸血量は 1 頭当り $500 \sim 10,100 \mathrm{cc}$ 平均 $2,155 \mathrm{cc}, 1$ 回当りの輸血 量は 300 2,000 cc 平均 $815 \mathrm{cc}$ である. 輸血開始から 終了までの日数は 1 70 日平均. 14.5 回であった.

これら 45 頭の延 119 回の輸血において, 臨床的に明 らかに副作用を発したものは 3 頭（震顫 2 頭, 肺水腫 1 頭）であった。

2.15例の輸血前後における臨床ならびに血液学的所 見

以上述べた 45 頭の輸血牛のうち 15 頭について, 輸 血前後に括汁る臨床ならびに血液学的観察を詳細に行な った.

この 15 頭は平均月令 16.9 カ月, 体重 $265 \mathrm{~kg}$ のホル スタイン種および短角種である. 輸血歴は $1 \sim 5$ 回平均 2.7 回, 輸血量は $450 \sim 1,200 \mathrm{cc}$ 平均 $605 \mathrm{cc}$, 輸血時間 は 5〜45 分平均 17.5 分間であった。輸血により副作用 を現わしたものは 2 頭であった。

副作用を認めなかった 13 例に和汗る輸血前後の体 温, 脈数, 呼吸数, 血圧の平均值には有意の差は認めら れなかった。また輸血を行ならことにより，13例中10例 において心音の強実を認めた。輸血前後の血液性状につ 
いては, 赤血球数, $\mathrm{Hb}$ 量, $\mathrm{Ht}$ 值, 血清蛋白量および 血清鉱物質（無機 $\mathrm{P}, \mathrm{Ca}, \mathrm{K}, \mathrm{Na}, \mathrm{Cl}$ ) を測定したが， 推計学的に有意の差は認められなかった.

副作用を発した 2 例の所見

第1例 (No.8) ホルスタイン種, 生後 8 カ月, 体重 $186 \mathrm{~kg}$, 小型ピロ沛肺虫症を合併, 赤血球数 281 万, 輸 血歴 4 回, 交叉試験 (一), 輸血量 $500 \mathrm{cc}$, 輸血時間 25 分.

輸血開始 10 分後より軽度の震顫, 呼吸促迫を認めた が輸血を続けた。輸血後血圧の低下，肺水腫の症状を発 した. 赤血球数抽よび血糖は急増し,グロス反応は増悪 した．強心処置を行なうことにより約 30 時間後に回復 した。

本症例はピロプラズマ病に肺虫症を合併した重篤なも ので，輸血中に震顫を現わしたのにもかかわらず，なお 輸血を続行したことが，肺水腫を惹起した原因のように 思われる。

第 2 例 (No.91) 短角種, 生後 8 力月, 体重 $150 \mathrm{~kg}$, ピ口原虫 $(+)$, 赤血球数 539 万, 輸血歴 1 回, 交叉試験 (一), 輸血量 $820 \mathrm{cc}$, 輸血時間 40 分.

輸血開始 40 分後, 突然震顫, 心悸圥進, 血圧の低下 を認めた. 血液の変化は血糖の急増, 血清無機P の減少 が主なる所見であった。輸血を中止することにより，こ
れらの症状は 20 分後に消失した.

本症例に和ける副作用の発現は, 過剰輸血によるもの と考えられる.

\section{総括}

1. 昭和 $37 \sim 38$ 年度において岩手県種山放牧地で は, 牛のピロプラズマ症 45 頭に対し, 延 119 回の輸血 療法が行なわれた. そのらち 26 頭の延 74 回の輸血は 第 2 回以降のものであったが，副作用を発したものは 3 頭各 1 回にすぎなかった。

2. 45 頭のうち 15 頭について, 輸血前後における臨 床ならびに血液学的観察を詳細に行なった．その結果 2 頭において副作用を発したが，他の 13 頭の輸血前後に 和ける臨床ならびに血液性状には有意の差を認めなかっ た.

3. 副作用を発した 2 頭のうち 1 頭は輸血中に震䫓を 現わしたが，採血を中止することにより約20分後に回復 した．他の 1 例はピロプラズマ病に肺虫症を合併した重 症例で, 輸血後肺水腫の症状を発したが, 強心処置を行 ならことにより約 30 時間後に回復した.

4. 以上の成績からピロプラズマ病に対する輸血療法 に拉いては，必ず交叉適合試験を行ない。輸血中ないし 輸血後において絶えず副作用の有無に注意すれば，十分 応用できるものと考えられる。

第99回日本臨床獣医学会 (中国) 期日 : 昭和38年 9 月26日, 27日 会場 : 松江市, 県庁講堂

\section{乳頭損傷等による乳漏症の整形外科治療について}

\section{井上皎}

乳牛の乳漏症は意外に多発する疾病であり, その発生 原因も種々あるが，外的起因によるもの，すなわち，蹄 炕上る踏創，放牧中有刺鉄線による裂創，あるいは， 他牛との争いによる損傷など，枚挙にいとまがない。こ れらの乳頭損傷による乳頭括約筋損傷, あるいは欠損に

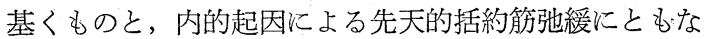
ら乳漏症とがある。これら乳漏症は直接間接に乳房炎を 惹起し, 泌乳能力喪失し, 廃用となる例も多く, 廃用と ならないまでも慢性乳房炎とか，泌乳量減少，あるいは 管理の非常な困難性など，経済的損失は極めて大であ る。優秀な乳牛を 1 瞬にしてこのような状態に陷入れる 本症に対して，いまだなんら根治療法は行なわれていな い. 私は数年来本症発症牛に対し, 更生を図る途はない ものかと研究を続けてきたが，1962年に至り，遂に「乳 漏症に対する乳頭筋層内物質埋没手術」とも称すべき， 乳漏防止手術を考察し，爾後，14 例に対し施術した結 果, 全例乳漏症を治瘾させることに成功したので, ここ に発表し，譇賢のご批判を願いたいと思う。

\footnotetext{
* 岡山辱農業共済組合連合会美作出張所
}

術式 乳頭断裂による乳漏症の場合は, まず第 1 次手 術として, 乳頭断面の整形手術を行ない，しかる後，第 2 次手術として漏乳防止手術を実施する. 乳頭断裂以外 のものに対しては第 2 次手術の㕛行なら.

第 1 次手術 (乳頭断端整形手術)

保定 細微な手術が多いので横臥保定をする。そして 前肢は前方に，後肢は後方に引張り開張させ，乳房を完 全に露出させる。この方法が人手を要せず危険がない.

麻酔 乳頭断面より, 乳頭皮下織, 粘膜下筋層内に, ボスミン加 $2 \%$ 塩酸プロカインを分注する.

手術 図のように皮膚，皮下織を残して，乳頭先端が 円錐形となるよう筋層を切除整形する: 乳頭先端に残し た皮膚は図に示したように 4 等分し，4枚の 3 角皮膚片 となるよう切除する。つぎに 4 枚の 3 角皮膚片で完全に 乳頭先端を被覆するよう，皮下織执よび皮膚を拉の括の 結節縫合する。つぎに 3 角皮膚片の先端は切除し図のよ うに，乳頭管断端と皮膚断端が確実に密着するよう，各 片ごとに結節縫合する．最後にチューブを装着し，第 2 次手術時なで装着しておく，抜糸は術後約 1 週間で行な 
5.

手術時間は約 30 分程度である.

第 2 次手術（乳頭筋層内物質埋没手術）

万針この手術は, 第 1 次手術の治瘾したもの, 乳頭 損傷により乳漏症を後遺したもの，および先天的括約筋 弛緩による乳漏症に対して行なら。すなわち, 乳頭先端 部の筋層内に加熱滅菌処理の流動パラフィンを注入埋没 し，乳管王迫により漏乳を防止する目的で行なう。

保定 手術は極めて簡単なので，起立保定で，とくに 施療側の後肢のみ枠に固定するか，あるいはカウキーパ 一を装置する。

麻酔，乳頭先端より約 $2 \mathrm{~cm}$ の間，皮下および筋層内 に゙ $2 \%$ 塩酸プロカインを分注する。

手術 乳頭管内に導乳管を挿入する。これは乳頭管内 に注入針が出ない上う検査するためと, 注入物質の圧迫 抵抗を調べるためである.

つぎに流動パラフィンの注入埋没であるが，図のよう に細い注射針を乳頭先端より刺入し，流動パラフィンを 乳頭筋層内に分注する. 注入は乳頭管口を中心として周 团数力所に行ない，注入量は挿入している導乳管を出入 して抵抗圧迫を感じる程度でよい，最後に乳房圧迫など により, 漏乳の有無を再確認して手術を終る. 以上手術 時間は約 10 分程度である. 後治療は必要ないが, 術後 㩁乳について注意すべきことは, 術後 3,4 日は埋没力所 を圧迫しないで，乳頭上部を圧迫して竹乳することであ る.

治験例 乳頭損傷によるもの 10 例, 先天的括約筋驰 緩によるもの 4 例, 計 14 例について本法を実施した が，全例治癒している. 乳頭損傷によるものの中で, 乳 管口は指が入る位の穴となり, 乳汁が絶光ず漏乳してい
る重症例も，本法により治痖している．先天的乳漏症の 場合は，第 2 次手術のみで極めて簡単に治癒している。

考察 1) 乳頭切断端の自然治痖は極めて長時日を要 するが，その間に細菌感染などのため乳房炎を起こし， 泌乳力衰失し, 不治となることがあるので, 第 1 次乳頭 切断端の整形手術は事故発生後, 直ちに, 必ず行なった 方がよいと思う．2）乳頭切断後時日を経過し，いまだ に皮膚の再生がない場合は，乳頭側面の皮膚面から注入 すると，物質の漏出がなく効を奏する，3）注入針は $1 / 2$ 針が適当と思う。太針を使用すると, 刺入孔から 物質が漏出し，完全圧迫量を注入埋没することができな い．4）注入埋沿に用いる物質は，少なくともつぎの条 件を備えていなくてはならないと思う。すなわち，「細 い注射針で注入できる流動体であること」「筋肉組織内 に入り吸収され難いもの」「組織に刺激を与えないもの」 「組織内で硬化，あるいは変質しないもの」「完全隇菌が できるもの」「入手容易で安価なもの」などである．前 記諸条件を満足させる流動パラフィンを使用した結果, 大変好成績を挙げることができた．5）、本法実施後，日 が経つにつれて，埋没した流動パラフィンは徐々に減少 する反面，その周囲に稍硬い肉芽増殖が起こり，その肉 芽による相乗的圧迫効果により, 乳頭管圧迫作用が継続 される。

和わりに 本症は適当な治療法がなかったため, 多く の乳牛が漏乳状態で非常な困難と損失を払いながら飼育 されているが，これらに対して1日も早く治療を施し， 酪農経営の安定を図ることが必要であろらと思う。私は 本法により，まず初期の目的を達成したと思っている が，より一層完成した術式を得るべく，諸賢のご指導と ご協力とを拉願いする。

第 100 回日本臨床獣医学会 (九州) 期日 : 昭和38年10月29日会場 : 大分市, 県庁ホール

\section{アルコール不安定乳の診療について}

佐 藤達*

アルコール不安定乳（以下陽性乳）の発生原因には種 々の説があるが，筆者も多年陽性乳の治療に当り難治の もの強肝剤を用いてしばしば好結果を得た経験があ り, 治療に当っていまず肝臟機能検査を行ないさらに野 外で行ない得る簡単な諸検査を併用しその原因を認めら れるところに従って治療すべきものであると考光, この 方針によって診療を行ない少数例ながら一応の結果を得 たので報告する。

\section{試 験 方 法}

（1）試験牛：当院に上診した陽性牛 28 頭㧍よび対照 牛として健康牛 12 頭他の病牛 2 頭を用いた。

* 大分県開業

日獣会誌 $\cdot 18$ (1965)
(2) 試験期日：1962年 5 月～1963年 9 月

(3). 試験方法

a 診断 一般診断の外

血清一高田法, ヨード法, モイレングラハト法, 尿 一uristix 試験紙， T T 試導

乳一P L,テスター, 東洋ろ紙, 糞一鏡検, 骨硬度,

b 供試薬品

ケトージン,ルノーゲン

肝臓機能障害 チオクタン, ヘキサメチオニン

卵巣のう腫 プベローゲン, ルテオーゲンL

乳房炎タルゴット，ベタログ，ペニコリフラシンゲ ル, 複方ヨード軟膏

子宮内膜炎 マストールE P, オルトシンに+マイシ 
リンゲルセプター

発情 ルテオーゲン,

その他 $50 \%$ ブドウ糖液十ビタミン $\mathrm{K}$ ，オスチール，

オスチーゲン，デューファー $\mathrm{AD}_{3} \mathrm{E}$, ニューグロン, カ ルチノミン, 薏药仁, $\mathrm{AD}$ 骨粉.

\section{結 果}

陽性乳として上診した 328 頭中妊娠分婏に関係あるb の 17 頭が最も多くつぎは肝蔵機能障害あるもの 14 頭 である.肝臓機能検査法の中黄疸指数を知るためモイレ ングラハト法を用いたがその結果はバラッキが多く陽性 牛群において平均 $10.58 \%$ 対照牛群において平均 $9.4 \%$ （妊牛を除く）を示し有意差を認めなかった．ただ妊娠牛 において稍高い傾向を示した.ヨード反応は陽性牛群で 陽性率 $61.54 \%$ を示し高田反応に比し著しく高率であっ た. 高田反応は陽性牛群に预いては $31 \%$ を示しお掠む ね臨床所見と一致した。

上記の諸検査を総合して診断した結果, 種々の原因が 単独にあるいは複合しているものと推察され就中肝臓機 能障害あるものが50\%に上ることを知った：治療につい ては産後のものが上診数の $50 \%$ を示し盛乳期に入り損 害も大である.この中には子宮の収縮が不合で復故の遅 れているものが多いので子宮内薬液注入を 1 ～回行な った結果 5 ～7 日で治療するものが多くそれで治らぬも のにはV.K+ブドウの混注で治った.

肝臓機能障害あるものに対しては強肝剤を $5 \sim 7$ 回連 注することにより好結果を得た。

妊娠 3 力月で陽転したものにベタログ $30 \mathrm{mg}$ を 1 回に 筋注し一時乳量が $60 \%$ に減じ強陽性となったものが 3 日後に乳量旧に復しアルコール反応が消えた。しかし 2 週間後にさらに陽転した。 また産後発生した 2 例にベタ
ログ 1 回量 $12 \mathrm{mg}$ を 2 回連注し乳房の硬結には著効があ ったが陽性乳には効果を認めなかった。

軽症に対してはオスチール，オスチーゲンの混注は効 果がある.

その他のものに対しては 50\% ブドウ 糖液 $300 \mathrm{cc}+$ $\mathrm{V} . \mathrm{K} 600 \mathrm{mg}$ を 1 回量とし $2 \sim 4$ 回連注することが最 も治療率が高い，この場合 $3 \sim 4$ 回注射して直ちに反応 が消えぬものでも，いくらか軽減する傾向のあるものは そのまま中止して 3 ～5 日も経過すれば治療する.

カルチノミン,オルトミは1回量 100〜150 ccを打の おの 4 回連注したが效果を認めなかった。しかしその原 料である薏药仁は漢方で消炎栄養改善などの目的で処方 されまた母乳嘴腫に特効あることは広く知られていると ころである。

デューファー $\mathrm{AD}_{3} 1$ 回量に $20 \mathrm{cc}$ 宛 2 回をおのおの 2 頭に用い効果なくブドウ糖 $+\mathrm{V} . \mathrm{K}$ の追注によって治っ

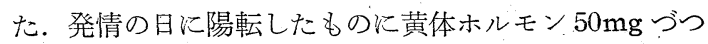
2 回連注して効なくこれもブドウ糖 + V.Kの追注によ って治癒した.

\section{結 果}

(1) 本症の原因は複雑であり就中肝臓機能障害と認む べきものが $50 \%$ の高率を示す.

（2）肝臟機能障害の検査法としては高田法が最も信頼 できる.ヨード法は陽性率が高きに過ぎる感があるので 補助として用らるが適当である。モイレグラハト法は乳 牛に対しては適当でないように思われる。

（3）治療についてはその発生因子がさまざまであるか らおの沶のその原因に従って工夫すべきものである.

(4) 飼養管理の改善は治療にも予防にも必須の条件で ある・

第 101 回日本臨床獣医学会 (東京) 期日 : 昭和39年 2 月23日：会場：東京都，獣医師会館

\section{犬の皮膚疾患に対するにアミノカプロン酸による治療試験}

\section{太田亭二* 猪 野 和 郎*}

血中にある Fibrinolysin あるいは Plasmin (以下 PL) と呼ばれる線維素溶解酵素が, Anaphylactic shock, Arthus 現象などのアレルギー性疾患あるいは Shwartzman 現象などに重要な役割を果しているとされ, 今日盛んに 追究されている．血中のP Lが高度に活性化されると蛋 白質を分解し，その結果産生されたPolypeptide がいろい ろな有害作用を示す物質となることが考えられる，P L が高度に活性化される疾患に対し，抗 P L剂により活性 化を抑制すれば，活性化によって生ずる病的症状の子防 あるいは治療ができるといら考えから，人の方において は産科領域あるいは皮膚科領域に抗 P L剂を応用し治療
効果をあげている.

われわれは，犬に蛙いても P Lの活性化による疾患が あるだろうといら考えから各領域に使用検討中である が，今回は発症要因が内的因子によると思われる皮膚科 領域の疾患犬 30 頭に対し抗 P L剂を用い, 治療効果, 副作用発現状態などについて検討したのでその概要を報 告する.

\section{実験材料和よび実験方法}

実験犬：皮膚疾患の原因が内部因子によると思われる 患犬 30 頭を対象とした。

供試薬品：PLの抗酵素剤イプシロンーアミノカプロ ン酸である第一製薬株式会社のイプシロンを用いた. 
Ipsilon 投与法による有効, 無効の比較

\begin{tabular}{|c|c|c|c|c|c|c|c|c|c|c|c|c|c|}
\hline \multirow{3}{*}{, } & \multicolumn{3}{|r|}{ 静 } & \multicolumn{2}{|l|}{ 注 } & \multirow[b]{2}{*}{ 注 } & \multicolumn{3}{|r|}{ 皮 } & \multicolumn{2}{|l|}{ 下 注 } & \multirow[b]{2}{*}{ 注 } & \multirow[b]{3}{*}{ 計 } \\
\hline & & 連 日 & 注 & 院 & 日 & & & 事 日 & 注 & 隔 & 鬲 日 & & \\
\hline & $\begin{array}{c}1 \text { 回の } \\
\text { 投与量 } \\
\mathrm{ml} / \mathrm{kg}\end{array}$ & $\begin{array}{l}\text { 効果発 } \\
\text { 現量 } \\
\mathrm{ml} / \mathrm{kg}\end{array}$ & $\begin{array}{c}\text { 投与総量 } \\
\mathrm{ml} / \mathrm{kg}\end{array}$ & $\begin{array}{l}1 \text { 回の } \\
\text { 投与量 } \\
\mathrm{ml} / \mathrm{kg}\end{array}$ & $\begin{array}{c}\text { 効果発 } \\
\text { 現量 } \\
\mathrm{ml} / \mathrm{kg}\end{array}$ & $\begin{array}{c}\text { 投与総量 } \\
\mathrm{ml} / \mathrm{kg}\end{array}$ & $\begin{array}{l}1 \text { 回の } \\
\text { 投与量 } \\
\mathrm{ml} / \mathrm{kg}\end{array}$ & $\begin{array}{l}\text { 効果発 } \\
\text { 現量 } \\
\mathrm{ml} / \mathrm{kg}\end{array}$ & $\begin{array}{c}\text { 投与総量 } \\
\mathrm{ml} / \mathrm{kg}\end{array}$ & $\begin{array}{l}1 \text { 回の } \\
\text { 投与量 } \\
\mathrm{ml} / \mathrm{kg}\end{array}$ & $\begin{array}{l}\text { 効果発 } \\
\text { 現量 } \\
\mathrm{ml} / \mathrm{kg}\end{array}$ & $\begin{array}{c}\text { 投与総量 } \\
\mathrm{ml} / \mathrm{kg}\end{array}$ & \\
\hline 有効群 & $\begin{array}{r}0.5 \sim \\
0.7\end{array}$ & $2.5 \sim$ & $5 \sim 16$ & $\begin{array}{r}0.6 \sim \\
1.4\end{array}$ & $\begin{array}{r}2.5 \sim \\
5.8\end{array}$ & $3.5 \sim 7$ & $\begin{array}{c}1.0 \sim \\
1.3\end{array}$ & $2.2 \widetilde{8.0}$ & $3.3 \sim 9.3$ & 0.9 & 1.8 & 4.4 & \\
\hline 頭 数 & & 5 & & & 7 & & & 7 & & & 1 & & 20 \\
\hline 無効群 & $0.3 \sim 1$ & & $2 \sim 8$ & 1.5 & & 7.50 . & $.45 \sim 1.3$ & & $5 \sim 9.3$ & 1.0 & & 7 & \\
\hline 頭 数 & & 3 & & & 1 & & & 5 & & & 7 & & 10 \\
\hline
\end{tabular}

投与法と投与量 : 種類, 年令, 性別などはなんら考慮 せず, 1 回量大型犬は $20 \mathrm{ml}$, 中型犬は $10 \sim 20 \mathrm{ml}$, 小 型犬は 5 10 ml を一応の基準とし, 一部のものはさら に増量し静脈内あるいは皮下に連日あるい:隔日に注射 した. No.26, 27 の 2 例は治療中二硫化セレン剤による ・洗滌を 1 回行なったが，その他はいずれもイプシロンの みを用い，他の薬品は全く用いなかった。

効果判定法：次回注射時すでに薬効を認めたものもそ れ以後若干継続投与し, 最終回投与後 $1 \sim 2$ 力月観 察 し，明らかに効果のあったものを有効とした。

副作用判定法: 投与後, 活力, 食欲, 体温, 心摶数, 呼吸数, 糞便の状態など一般臨床所見の変化を一応の指 針とし，また一部について投与前後に和ける血球数，血 色素量, 白血球百分率などの所見を調べ総合判定した。

\section{実 験 成 績}

本剂は静脈内または皮下注射のいずれにおいても一般 臨床所見で副作用の発現と認めたものは 1 例もなく，ま た皮下注射において注射時および注射後の疼痛感は全く 認めず，一部のものに皮下に基準量の倍量を注射したも のでも翌朝にはいずれの例も腫脹を認めず吸収速かであ った。薬効は早いものでは 2 回目に゙すでに認めたが， No. 26，27のごとく10回目位に認めたものもある.一般 に 5 回前後で効果発現を認めた. 最終判定時明らかに効 果を認めたものは 20 例 $66.7 \%$ であった。

効果を認めたもの，無効だったものの一部について検 査した血液所見は両者の間に著しい差はなく，また両群 ともイプシロンによる影響はなんら認めなかった。

\section{考察}

血中 P Lを活性化する諸因子は多いが，PＬの活性化 と大の皮膚疾患との関連については未だ不明の点が多い 現状から，犬の皮膚疾患へ抗 P L 剂の適応症があるかを 検討したところ30例中. 20 例 $66.7 \%$ に効果を認めた. このことから犬にも P L 活性化を示すよらな疾患が相当 あることを伺いうる1資料を提供したものと考える．有 効のものと, 無効のものとを投与部位, 投与量, 投与間
隔などについて一括すると第 I 表に示すごとく，両者間 に有意差は認められなかった。無効のものが P L活性化 をさたすような疾患でなかったものか，本剤をさらに継 続すれば効果を認めたものかは，血中ＰＬの活性値を測 定していないので不明である.今後は血中 P L 值と各疾 病および抗 P L 剤との関連について検討したい.

\section{結 言}

1）内部因子による皮膚疾患犬 30 頭に抗 P L剤イプ シロンを使用し 20 頭 $66.7 \%$ に効果を認めた。

2）効果を垫めたものは, 静脈内, 皮下注射いずれに よっても一般に 5 回前後から発現し始めるようである.

3）副作用は全例に全く認めなかった.

4）本剂の又にて皮膚疾患治療を期待するのは，早計 であるが, 難事例に対し本剤の使用は時に著しい効果を 認めることもあることから, 皮膚疾患に対しては一応試 むべき薬剤と考える。

終りに本実験にご懇切なご指導を賜った恩師日本大学 農獣医学部小堀教授に事心より感謝の意を表します．試 供品を一部ご提供下された第一製薬株式会社に謝意を表 します。

日獣会誌 18 (1965) 


\section{日本獣医公衆衛生学会昭和 38 年度褒賞論文要旨}

第59回日本獣医公衆衛生学会（関東）期日：昭和38年 6 月11日 会場：鎌倉市，神奈川県鎌倉保健所講堂

安房に括ける乳質改善の 1 考察について

森弘*

生乳恃生産の形態からいわゆる専業乳と農家で生産さ れる酪農乳とにわかれているが，当管内で生産される生 乳はすべて酪農乳であって, 昭和 37 年においては搾乳 農家数約 4,500 戸，㩁乳頭数約 6,500 頭，摍乳組合（農 家数戸ないし 10 数戸をもって㩁乳組合を作っている) 約 380 ,生産乳量 $28,900 \mathrm{t}$ でこれらの生乳は管内 10 集 乳工場に搬入され，東京都技よび神奈川県に移送されて いる.

酪農乳は専業乳と異なり構造または管理の不備な畜舎 で, 㩁乳室, 取り扱い室などの施設がなく,かつ, 牛体 の管理も季節によっては十分行なわれないなど，不適当 な環境のもとで控乳され取り扱われているため, 細菌の 混入污染の機会はきわめて多く，乳質を低下させる原因 となっている。したがって摍乳あるいは，取り扱い中に 拈ける細菌の混入污染を防止し，すみやかにできる限り 低温に保持することが乳質改善には最も重要な手段であ り，そのためには乳質改善の必要性を生産者が理解して 積極的に改善意欲を高める必要がある.よってつぎに揭 げる指尊要項に基き指導を行なった。

(I) 指導要項

1. 単一挨乳組合, 地区酪農組合を対象として講習 会，あるいは座談会などを開催して衛生知識の向上をは かる。

2. 搾乳衛生指導員制度を設け各搾乳組合から推萀さ れた 1〜2 名を㩁乳衛生指導員となし, 毎年 $2 \sim 3$ 月中，

* 千葉県館山保健所
に搾乳衛生指導員講習会を開催し各組合の指 導 者とす る.

（II）組織活動を育成して計画性をるたせせ

酪農組合が自主的汇行なう乳質改善事業を育成し搾乳 衛生指導員の活勳を指導し計画的にかつ継続して行なわ せる.

（III）㩁乳組合が自主的に乳質管理を行なわせる

組合が組合員個人個人の生乳の検査を行ない，その成 績に基いて㩁乳施設の巡回指導, 搾乳力法の指導なぞを 行なら。

（IV）個人別の乳質検査を励行させる

細菌検査は生産者が自ら行ならことはできないので搾 乳衛生指導員がサンプルを採取し工場洋付して検查を 行なう.

\section{結 論}

1. 昭和 35 年上り昭和 37 年の 3 力年の生乳細菌検 查成績を比較すると，1４月，10１2月は 92〜99\%が 規格 $1 \mathrm{cc}$ 中 400 万以下で $5 \sim 9$ 号に扮いてはやや低下 する傾向がある.

2. 乳質の安定している組合と, 時に規格外に低下す る乳質不安定な組合とが区別され，今後, 乳質不安定な 組合に対してはさらに強力な指導を行なう。

3. 個別検査においても常に乳質の良好なるのと，不 安定なものとが明確にされるため, 乳質改善意欲をたか める.

第60回日本獣医公衆衛生学会（中部）期日：昭和 38 年 7 月 12 日，会場 : 富山市, 県町村会館

和菓子類に寄生する真菌の検索について

\section{上田貞善* 田中政美* 大崎 純* 山崎茂一* 坂井駒子*}

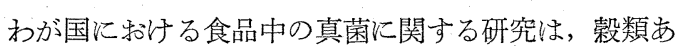
るいは酵母の利用を対象としたものは多いが，衛生学的 見地から研究を行なったものは少なく、わずかに寺沢の 市販牛乳, 稲垣らの脱脂粉乳, 肉類, 粉末状食品, 佐々 木のバター, 長瀬らの酸酵乳ならびに乳酸菌飲料, など があるにすぎない，そこでわれわれは食品，とくに和菒 子類の真菌検索を行ない，2，3の知見を得たので報告

\footnotetext{
* 富山県衛生研究所
}

する。

\section{検査材料和よび検查方法}

供試材料は富山県下で製造し市販されている製品で， 昭和 35 年 5 月 6 日より同 15 日までに採集された 157 検体のうち,主としてアンコを使用した和菒子 49 , インス タント食品 4 , 脱脂粉乳 7 検体である. 系状菌の分離に は, Czapek's agar そ. Sabouraud agar, 酵母は, Sabouroud agar そ Poteto Dextrose agar を使用し，大腸 
菌群は, B.G.L.B. 培地で定性試験を行なうとともに, 一般生菌数は, 標準寒天を用いて算定した.

\section{結 果}

1) 菌の検出状沉

第 1 表にみられるょらに糸状菌, 酵母ともに検出頻度 は高く, また製品の約半数は大腸菌群による污染を受け ていた．検出した真菌を分類してみたところ, 藻菌類, 子囊菌類, 不完全菌類で, 頻度の高かったものは Penicillium, Aspergillus, Yeast, Cladosporium などで 11 属 133 株を分離した。

第 1 表 真菌の検出状況

\begin{tabular}{|c|c|c|c|}
\hline 項目 & 糸状菌 & 酵 母 & $\begin{array}{l}\text { 大腸菌群 } \\
\text { 陽性 }\end{array}$ \\
\hline $\begin{array}{ll}\text { 菓 子 } \\
\end{array}$ & $43 / 49(87.8)$ & $30 / 49(61.2)$ & $22 / 49(44.9)$ \\
\hline インスタント， & $4 / 4(100.0)$ & $1 / 4(25.0)$ & $0 / 4(0)$ \\
\hline $\begin{array}{c}\text { 脱 脂 粉 乳 } \\
\text { 計 }\end{array}$ & $\begin{array}{r}6 / 7(85.7) \\
53 / 60(88.3)\end{array}$ & $\begin{array}{c}0 / 7(0) \\
31 / 60(51.7)\end{array}$ & $\begin{array}{r}0 / 7\left(\begin{array}{ll}0\end{array}\right) \\
22 / 60(36.6)\end{array}$ \\
\hline
\end{tabular}

各検体について大腸菌群と真菌の関係を検討した結 果, 大腸菌群, 酵母ともに陽性14検体, 大腸菌群のみ陽 性 8 検体，酵母のみ陽性16検体であった。㐬た糸状菌と の場合も同様に，21検体，1検体，32検体であった。 そ こで細菌污染の指標である大腸菌群と酔母（一致度の検 定で Pr.=0.144)あるいは糸状菌の間汇は，有意性がな く大腸菌群陽性が真菌污染の指標にはならないと思われ る.

3) 細菌数と真菌数の関係
第 1 図 細菌数と真菌数の関係

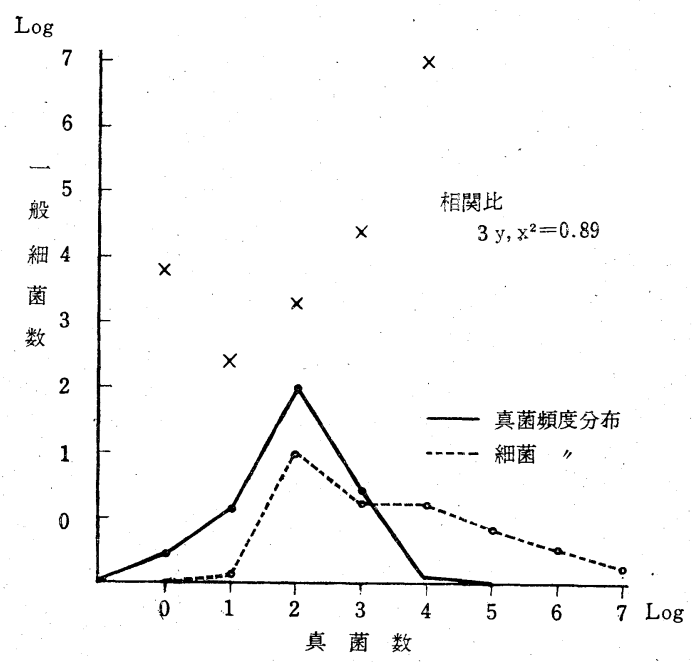

同一検体から検出された細菌数と真菌数の相関を検討 した結果, 直線性は認めなかったが細菌の検出頻度 $10^{2}$ $>10^{3}$ の間が 20/60 検体, 同様に真菌は 30/60 検体で頻 度分布は同じょうな傾向を示した。ささらに相関比にうい て検討をしたところ，第1図にみられるょうな曲線性で 相関比 $3 y^{x_{2}}=0.89$ となり有意性があるので, 一般細菌 数の多い検体は真菌数も多いと思われる.

\section{むすび}

以上のことから私達は，主としてアンコを使用してい る和菓子類に执いては, 真菌の污染度が高い事実を知 り, かつ一般細菌数と真菌数には高い有意な相関を示す 成績が得られた。な缷真菌の污染経路については今後検 討する予定である.

第61回日本獣医公衆衛生学会（四国）期日：昭和38年 7 月24日 会場 : 松山市, 井関農機(株)ホール

乳処理過程に抢ける牛乳の污染源追究と保存性について

倉 田義，夫*

衛生行政指導上, 取り扱いの向上等衛生管理の適正化 と牛乳の品質向上を図るため法定殺菌法別に milkplant での原料乳受入から処理過程に拈ける細菌の消長ならび に各種殺菌方法別にみた殺菌効果などについて検討を行 ないその污染源の穾態を把握するとともにさらに販売過 程に执ける保存性について試験検査をした結果, いささ か知見を得たのでここに報告する。

1). 乳処理場に护活る今回の細菌学的検查成績からみ て乳処理工程にみられる牛乳の污染はホモゲナイザー, クーラーなど, 殺菌工程以後の終末過程に打いてはなは だしいすなわち下部工程に移行するにしたがって細菌

\section{* 愛媛県今治保健所}

日獣会誌 18 (1965)
数は漸增する。前述のとおり牛乳処理場として最もよく 整備されているA処理場は衛生管理が比較的よく徹底し ているためか一般細菌数は処理過程拉よび牛乳容器 (空 びん), 紙恮など衛生状態も良好であったのは一応当然 の帰結とい光る。これに対し，B，C処理場飞执いては 終末工程和けるクーラー以後の污染度からみて器械器 具の清浄殺菌不備が目立ち，2次的污染防止の対策とし て今後これら衛生上の盲点に, メスを加兄適正なる殺菌 管理上の万全を期さね攼ならないものと考光る.

2） 3 種の加熱殺菌法の優劣は細菌学的試験検査の結 果からみて明らかのと打り，A処理場に和汗る超高温瞬 間殺菌法が他の 2 法を凌駕していることはまったく異論 のないところである。 
低温保持式殺菌法と高温保持式殺菌法の殺菌効率比較 においては，高温の方がやや優れているようであるが雨 者間の著しい較差はみられなかった。

3）牛乳の保存性を冷蔵温度と時間的経過に上る相関 についてみると本実験では, 冷蔵保存区の内 $5{ }^{\circ} \mathrm{C}$ の保存

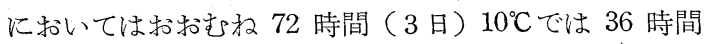

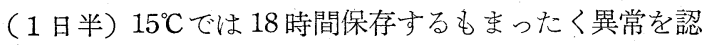
めなかった。すなわち冷蔵温度が $5{ }^{\circ} \mathrm{C}$ 上昇するごとに保 存時間が $1 / 2$ 以下に半隇するという結果がみられた。

換言すれば冷蔵温度の低いほど細菌の発育を抑制し保存 性を增すことはもちろんであって, 保存温度が逆に上昇 するにしたがって幾何級数的に增殖し, また化学的性状 に执いても比例的，可及的に変化を招くことは論をまた ない。

な打常温放置の結果からみると夏期冷蔵庫からとりだ した牛乳は常温放置では菌增殖の好条件となるためその 後の時間的経過とともに必然的に変敗, 腐敗の過程をと るもので夏期なれば数時間で外気温に達することは容易 であり；室外保管（常温）はきわめて危険であることは いうまでもない。

4）打のおの 3 種の殺菌法別に製品の保存性を比較検 討してみると本実験の結果では明らかに超高温瞬間殺菌 法 $\left(135^{\circ} \mathrm{C} 2\right.$ 秒間加熱殺菌) によるA製品の保存性が最 も高く他の 2 法の製品より群を拔いて優れていることを 確認した.

また，低温保持式殺菌法（63 $65^{\circ} \mathrm{C} 30$ 分加熱殺菌） および高温保持式殺菌法 ( $75^{\circ} \mathrm{C} 15$ 分加熱殺菌) の両者 の製品の保存性の比較では大差なきも今回の成績ではC
製品がやや優れていることを認めた。

ただ今回の実験成績から超高温瞬間殺菌法ではこれま での殺菌方法で十分破壊し党ない芽胞形成菌や熱抵抗菌 をも破壊する一大長所を有するといわ礼ているが，所謂 貯蔵中に生ずる分解産物による風味の悪化を防ぎ新鮮度 を長時間維持，持続することは今回の実験結果からみて も明らかで，かつその殺菌方法と保存性はきわめて密接 不可分の関係を有している.

なお，販壳店哺に括ける牛乳保存性の実態については 乳処理, 処理後の保管, 輸送などの各条件のほ汸, 販売 店舗に和ける取り扱いの状況などにより異なることはも ちろんであるが，これらの実態を把握し，その指標をら るためには各種条件下において綿密な検討を加えねばな らないものと考光る.

以上述べてきたこの種の研究に関しては識者による幾 多の学究的研究があるが，今回の試みは冒頭にも述べた と和りあくまで衛生行政指導上実態把握のために行なっ たささやかな一連の実験成績であって今後さらに実験の 補正と学究的に一貫した系統的な追究にまたねばならな いことはもちろんであり, 所謂, 行政の科学化を推し進 めより一層行政上の効果をあげてゆく上から, 本実験成 績を今後乳処理施設改善指導上の参考とし，さらにこれ をもとに追試検討を加光たいと念願する次第である.

終りに本実験を実施するにあたり種々ご協力いただい た愛媛酪農々業協同組合注か各乳業関係者各位に厚く掠 礼申上げるとともに本実験について終始ご援助, ご助言 いただいた今治保健所衛生課鷹本隆夫技師, 試験室村上 義信技師ほか各部員の方々に対し謝意を表します.

第62回日本獣医公衆衛生学会（近畿）期日：昭和38年 8 月18日 会場：神戸市，中小企業労使センター

\section{淡路島岩屋，江井海域の大腸菌群並びに一般細菌数について}

\section{太田喜和二* 富 岡 南 生*}

近年, 魚介類による食中毒は主に病原性好塩菌である ことが報告され，周囲が海にかこまれている淡路島にお いても 1 昨年来病原性好塩菌による食中毒が散発してい ることに注目し，好塩菌の分布状況を調查する一環とし て，まず昨年 $7 \sim 8$ 月にわたり海水浴場としてにぎわら 大阪湾の 1 局部にすぎない岩屋海水浴場海域と播磨灘に 面する江井海水浴場海域を対象として, 環境衛生および 食品衛生学的基礎資料を得るために当調查を行なった．

[実験材料和よび方法] 実験に供した海水は両海域と もに陸地上り A B C の各線とその線上に各採水定点を設 けた。海水の採水に当っては滅菌ハイロ一ト採水器 $(250$ cc) 使用し, 水面下約 $1 \mathrm{~m}$ より採水した. 採水した海 水は直に実験室に持ち帰り, 厚生省編衛生検査指針記載

\footnotetext{
* 兵庫県津名保健所
}

の方法により検查を行ない，以後大腸菌群陽性のものか ら Imvic-System により大腸菌群の菌型を分類した。な 敃海水細菌と培地の塩分濃度との関媇について今回はそ れに触れずに実施した。 また，採水時の気象状況につ いて両海域ともに採水時間, 風速, 潮位など実験值つ 誤差を生じさせないために比較的同条件のもとで採水し た.

〔調查結果〕（1）岩屋海域の一般細菌数については, 陸地より $30 \mathrm{~m}$ 離れた $\mathrm{A}$ 線上において最高 $34,000 / \mathrm{cc}, \mathrm{B}$ 線上では 4,900/cc，C線上では 9,000/cc であった。一 方, 江井海域の一般細菌数については, A線上の最高は 江井港の $17,000 / \mathrm{cc}, \mathrm{B}$ 線上では $60,000 / \mathrm{cc}, \mathrm{C}$ 線上では B線と同様 $60,000 / \mathrm{cc}$ であった.

(2) 岩屋海域の大腸菌群 MPNKついては最高 $310 / \mathrm{dI}$ 日獣会誌 18 (1965) 
であり，B線上においては 45/dl，C線上では 20/dl で あった. 一方, 江井海域の大腸菌群 MPN はA線上で 最高 $3,500 / \mathrm{dl}, \mathrm{B}$ 線上では 790/dl, C 線上の最高は 140/ dl であった。

（3）岩屋海域より分離した大腸菌菌株を Imvic-System により分類したところ, E.coli I 型 3 株, E.coli II 型 4 株, A.aerogenes I 型14株, 同 II 型 2 株, Inter mediate I 型 5 株, 同II型 2 株, Other type 9 株であ った. 一方, 江井海域の大腸菌菌型については, E.coli I 型 4 株, 同 II 型 1 株, A.aerogenes I 型10株, 同 II 型 2 株, Inter-mediate I 型 5 株, Inter-mediate II 型 1 株, other type 4 株であった.

岩屋および江井海域より分離された大腸菌菌株 66 株 の菌型を委とめると， E. coli I 型 7 株，同 II 型 5 株, A.aerogenes I 型24株, 同 II型 4 株, Inter-mediate I 型10株, 同而型 3 株, other type 13株であった.

[考察]、昭和 37 年 $7 \sim 8$ 月にわたり海水の污染調査 を行ない，前述のような結果を得た．海水の污染調査に ついては三浦（1954～1956）などは大阪湾で調査をした 結果，沿岸部に拈いて一般細菌 $40 \sim 18,000 / \mathrm{cc}$, 大腸菌 群MPN 1, 700/dl であったと報告している. 佐藤(1956) などは東京港の海水を調查し一般細菌 20６8,000/cc, 大腸菌群 MPN 490 65,000/dl と報告している，一方 東京港と他港との污染度を比較し, 新潟港の一般 細 菌 $17,000 / \mathrm{cc}$ ，横浜港は $22,000 / \mathrm{cc}$ ，小樽港 $1,100 / \mathrm{cc}$, 門司 港 1,900/cc であり, 大腸菌群M P Nで媇港 91,000 $/ \mathrm{dl}$ ，横浜港 $29,000 / \mathrm{dl}$ ，小樽港 $1,400 / \mathrm{d} 1$, 閒司港 2,600 /dl と報告している. また細谷（1959～1960）は横須賀 馬堀海水浴場海域の調査を行ない一般細菌 $150,000 / \mathrm{cc}$, 大腸菌群 MPN 1,800/dl であったと報告している。ま た神戸検疫所（1962）は神戸港を調查し一般細菌60,000 /cc，大腸菌群 MPN 160,000/dl であったと報告してい る、これなどの調査報告とわれわれが行なった結果を比 較してみると，横須賀馬堀海水浴場海域の調査結果と比 較的近い値である.海水浴場の判定基準では大腸菌群 $\mathrm{M}$ P N 10,000/d1 以下の海はき机いな海, 10,000 50,000 /dl では泳いでる差しつかえない，50,000/dl 以上では 適当でないとされているがこの数值と比較すると岩屋， 江井両海域とも海水浴場として適当である.しかし，江 井海域中江井港の大腸菌群M P N
港, 門司港より約 $2 \sim 3$ 倍量であり,一般細菌数は東京, 新潟, 横浜, 小樽, 門司のそれとは $2 \sim 3$ 倍量であっ た.かかることから江井港はいかに活染度が大であるか を示している：江井港の污染度のはなはだしいことは沿 岸住家がし尿処理の困窮から同港に投棄し, あるいは, 往来船船からの投入などが海水污染の大きな要因となっ ていることが考觉られ，沿岸各町においては早急にし尿 処理対策を樹立する必要がある．また，細谷などは一般 細菌数は沖合へ遠ざかるにしたがって減少する傾向があ ると報告しているがわれわれの行なった結果ではB線よ りC線上の方が大のところもあうた。一方大腸菌群は 減少する傾向が認められた．このことについては武原 (1959)はクロールイオン濃度の低い海域より多くの生菌 数を得たと報告している.つぎに Imvic-System により 分類してみると A. aerogenes 型 B. Intermediate 型が 多く検出されたが，このことについて八田（1948）は， A.aerogenes 型は E.coli 型より直射日光など外界の条件 に対する抵抗力が強く E.coli 型より長く生存すると報 告している. 一方 E.coli 型が比較的多く分離されたこ とは佐藤などの報告から推測するに人畜の排泄物が直 接, 間接に混入していることになり, 食品衛生上拉よび 環境衛生学的に興味ある問題である.

〔結論〕（1）岩屋, 江井海域の污染度は想像以上であ った.

（2）全採水定点中，21採水定点より大腸菌群が検出さ れだ。

（3）大腸菌群の最高は江井港の $3,500 / \mathrm{dl}$ であった.

(4) 一般細菌数の最高は $60,000 / \mathrm{cc}$ であった.

（5）Imvic-System により菌型を分類した結果，E.coli 型 $10.5 \%$, 同 II 型 $8 \%$, A.aerogenes I 型 36\%, 同 II 型 $7 \%$, Intermediate I 型 $15 \%$, 同II型 $4 \%$, othertype $19.5 \%$ であった.

（6）環境衛生学的見地より，(A) 両海域とも海水浴場 とし良好である. (B) 沿岸各町に执いては亡尿処理対策 を樹立する必要がある。

（7）食品衛生学的見地より，(A) 港の内部は污染度が 高く, 病原性好塩菌などの発育が盛んであるので, 港内 の海水で魚介類を洗滌することは適当でない（B）海苔 貝類の養殖場としては汇井港周囲を除いては適当であ る。 
第63回日本獣医公衆衛生学会（北海道）期日：昭和38年 9 月 7 日 会場：岩見沢市，市民会館

\section{乳質改善事業に和ける断熱水槽の効能}

\section{蒲田 衞* 樋渡五郎* 村井満寿男* 山岡了三* 大谷元彦* 後藤宗久*}

高妻正和* 淵脇逸郎*

\section{緒 論}

われわれは乳質改善のための 1 手段として，これによ る経済的効果を生産者に強調してきているが，この線に 沿って貯乳用の簡易な断熱水槽の考案と普及をはかり，

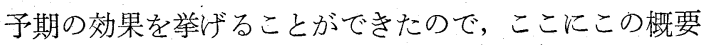
を報告する。

\section{断熱水槽}

\section{A 構 造}

簡単で安価，しかもより効果的であることをねらい， 従来のコンクリート水槽を断熱水槽に改良した，その方 法はつぎのと叔りである.

\section{1 断熱水槽の設計}

乳量によって大きさをきめるが，普通輸送缶 4 〜 6 本 入る大きさで十分である。この断熱水槽ば予冷槽があっ て一層の效果が上るので，かならず予冷槽を併置する. また本冷槽には断熱性の蓋を設ける。

\section{口 断熱水槽壁の構造}

図1飞示されるように, 従来の水槽 $\mathrm{a}$ 亿対し, 断熱水 槽では既設コンクリート水槽を改造するときはc のよう に，新設のときはdのようにする。

図1 従来の水槽々断熟水槽の構造比較（横断面）
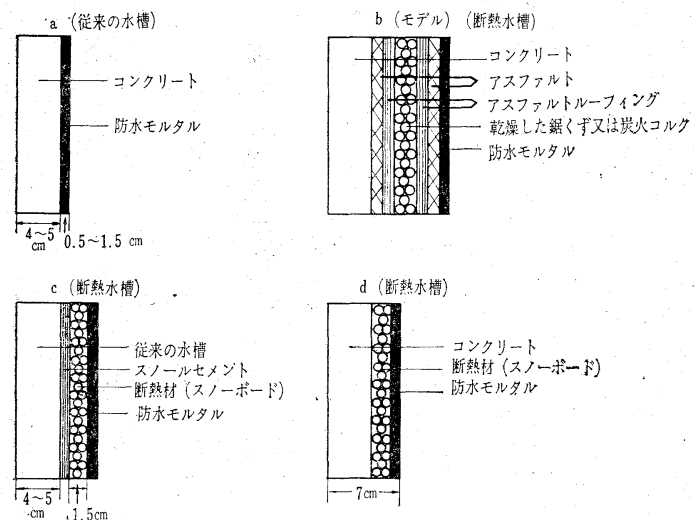

c 亿扬いては従来のコンクリート水槽に対してまず接 着剤スノールを塗布した後断熱材スノールボードを貼布 し，さらにその露出面に防水モルタルを塗る.

$\mathrm{d}$ に和いては，断熱材を中心にしてカタワクの中に流 し込むことによってできる。

\section{·B 製作費}

表 1 断熱水槽製作費 新設（内径 $110 \times 70 \times 60 \mathrm{~cm}: 6$ 本入）

\begin{tabular}{|c|c|c|c|}
\hline 品 & 数量 & 単 価 & 計 \\
\hline セメント & 4 袋 & 400円 & 2,400円 \\
\hline 洗砂, 砂利 & & $800 \sim 1,000$ & $800 \sim 1,000$ \\
\hline \multicolumn{4}{|c|}{$\begin{array}{l}\text { 断熱材 }(\text { スノーボード) } \\
\text { (厚さ } 1.5 \text {, 大きさ } 91 \times 182 \mathrm{~cm})\end{array}$} \\
\hline & 4 枚 & 375 & 1,500 \\
\hline 防水ベニヤ & 1 枚 & 380 & 380 \\
\hline $\begin{array}{c}\text { 排水管, 蝶番, } \\
\text { 計 }\end{array}$ & & 1,000 & $\begin{array}{c}1,000 \\
6,080 \sim 6,280\end{array}$ \\
\hline
\end{tabular}

改良の場合（8本入れまで）

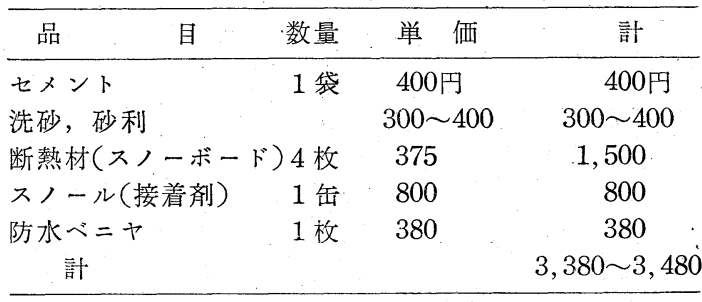

表 1 飞示されるように新設の場合では約 6,000 円, 改 良の場合では約 3,000 余円で仕上げることができる。

\section{C 耐熱効率}

図 2 亿示されるように $16.3^{\circ} \mathrm{C}$ の水を 24 時間貯蔵し た際, 従来の無蓋コンクリート水槽では $19.7^{\circ} \mathrm{C}$ を示し たのに対し断熱水槽では $17.1^{\circ} \mathrm{C}$ に止っていた。

図 2 : 断熱水槽による耐熱試験

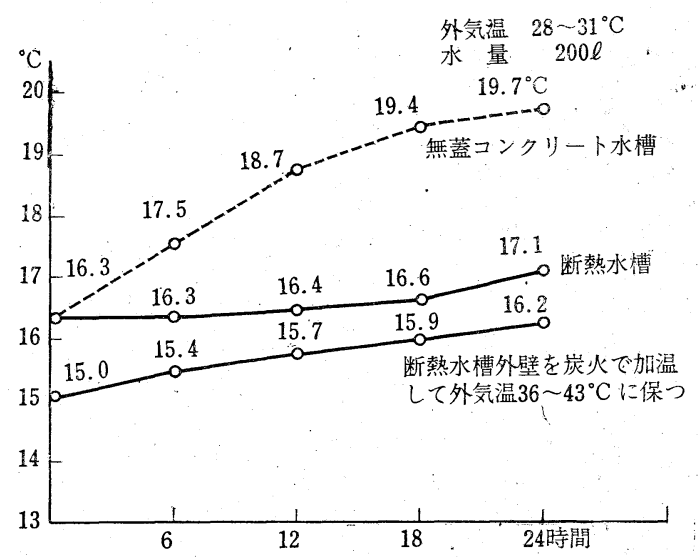

断熱水槽を用いて実際に乳を冷却した際の成績を図 3 に示すが, 冷却水温 $14^{\circ} \mathrm{C}$, 乳温 $33^{\circ} \mathrm{C}$ の場合, $18 \mathrm{~kg}$ の

日獣会誌 $18^{\circ}(1965)$ 
図 3 断熱水槽使用 例

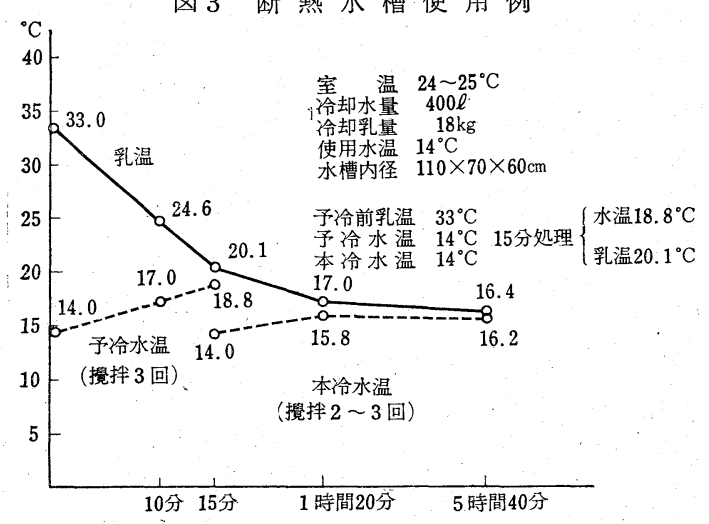

乳ではまず予備槽内に 15 分冷却した後本槽に移すと き, 冷却後 5 時間 40 分で $16.4^{\circ} \mathrm{C}$ に下降している.

さらにこの断熱水槽と市販伶水装置 $(52,500$ 円) を併 用するときは，その泠却効率はきわめて顕著となる，そ の 1 例を図 4 に示したが，本例では冷却後 6 時間で乳温 はすでに $7.4^{\circ} \mathrm{C}$ にで下降し，この間の消費電気料は 23.1円にすぎない。

図 4 断熱水槽と冷却機を併用した際の成績

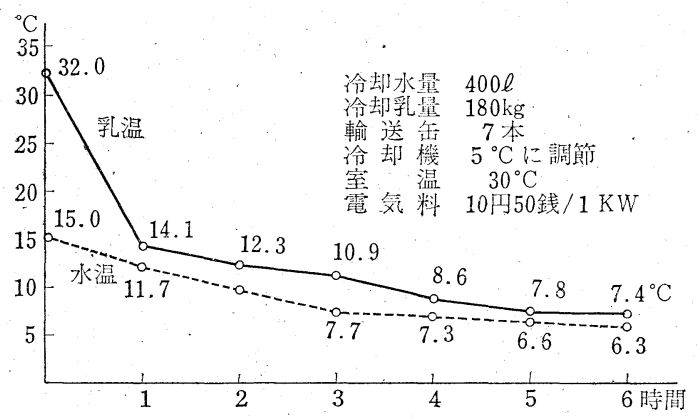

\section{D 断熱水槽使用酪農家の経済効果}

表 2 に 3 例を挙げたが, 断熱水槽のみを設けることに よっても多大の効果を挙げている.

な扣断熱水槽と市販冷水装置とを併用した農家ではさ らに期待した効果を挙げている.

な批熱水槽を使用した農家と未使用農家とに和ける 落等率の比較を表 $3 \mathrm{~A}, \mathrm{~B}$ に示したが, 断熱水槽単独使 用例に打ける,さらに冷水装置を併設した農家に和ける 落等率はきわめて減少している。

冷却装置を設けることにより 2 等乳が減少した結果, これによる乳代の増加により 1 夏を経ずして断熱水槽設 備費を捻出することができ，大量乳生産者に捻いては市 販冷水装置代をも回収することができた。な扔断熱水槽 の利用は独り夏季の高酸乳の発生を防止することができ るばかりでなく,さらに冬季た利ける凍結乳の防止をも 期待できる点に执いて従来のコンクリート水槽より勝っ
表 2 断熱水槽のみ使用酪農家の実際例 例 乳代 1 等乳量 2 等乳量 1 等乳代 2 等乳代 乳代総計

\begin{tabular}{|c|c|c|c|c|c|c|}
\hline & 6 月 & $\begin{array}{r}\mathrm{kg} \\
463.0\end{array}$ & $\begin{array}{r}\mathrm{kg} \\
209.0\end{array}$ & $\begin{array}{r}\text { 円 } \\
13,579\end{array}$ & $\begin{array}{r}\text { 円 } \\
3,588\end{array}$ & $\begin{array}{r}\text { 円 } \\
17,167\end{array}$ \\
\hline & 7 月 $* 20$ & 531.6 & 155.1 & 15,591 & 2,663 & 18,254 \\
\hline & 8月 & 773.6 & 0 & 22,689 & 0 & 22,689 \\
\hline 例 & 8 月 $* 15$ & $3,576.0$ & 146.0 & 104,884 & 2,506 & 107,390 \\
\hline & 9月 & $3,131.9$ & 27.0 & 8 & 463 & 92,321 \\
\hline & 7月 & $3,226.5$ & 188.9 & 94,633 & 3,260 & 97,893 \\
\hline 例 & 8 月 $* 20$ & $2,203.3$ & 88.3 & 64,622 & 1,516 & 66,138 \\
\hline & 9 月 & $1,748.2$ & 0 & 51,274 & 0 & 51,274 \\
\hline
\end{tabular}

○乳代計算法 (原料価額) 1 等乳 $3.2 \%$

$1 \mathrm{~kg}$ 当り $\begin{aligned} & 27 \text { 円 } 10 \text { 銭 }+2 \text { 円 } 13 \text { 銭 計 } 29 \text { 円 } 33 \text { 銭 } \\ & 17 \text { 月 } 17 \text { 銭 }\end{aligned}$

（円以下は五捨六入で計算）

* 断熱水槽を使用し始めた月日

表 3 管内の冷却装置を設けた酪農家と一般酪

農家 183 軒の落等率比較

A 断熱水槽のみ使用例（9 軒）

\begin{tabular}{|c|c|c|c|c|c|}
\hline 月 & 別 & 1 等乳量 & 2 等乳量 & 落等率 & $\begin{array}{l}\text { 本例以誃の農 } \\
\text { 家の落等率 }\end{array}$ \\
\hline 38年 5 & & $15,446.2 \mathrm{~kg}$ & $323.6 \mathrm{~kg}$ & $2.09 \%$ & $3.56 \%$ \\
\hline & 月 & $17,707.0$ & 171.5 & 0.96 & 3.61 \\
\hline & 7 月 & $16,197.2$ & 379.1 & 2.34 & 5.98 \\
\hline & 8 月 & $15, \dot{4} 59.1$ & 562.9 & 3.64 & 8.23 \\
\hline
\end{tabular}

B 断熱水槽と冷水装置併用例 ( 7 軒)

\begin{tabular}{|c|c|c|c|c|c|}
\hline 月 & 別 & 1 等乳量 & 2 等乳量 & 落等率 & $\begin{array}{l}\text { 本例以外の農 } \\
\text { 家の落等率 }\end{array}$ \\
\hline 38年 5 & & $26,745.4 \mathrm{~kg}$ & $210.1 \mathrm{~kg}$ & $0.78 \%$ & $3.56 \%$ \\
\hline & 月 & $31,608.8$ & 274.6 & 0.86 & 3.61 \\
\hline & 7月 & $30,405.4$ & 369.5 & 1.30 & 5.98 \\
\hline & 8月 & $28,302.8$ & 625.2 & 2.20 & 8.23 \\
\hline
\end{tabular}

ている。

断熱水槽中の水は清潔を保つために，夏季はかならず 毎日入れ換え，冬季間でも 4 日を経過してはならない。

ただし，夏季，氷塊を $4 \sim 8 \mathrm{~kg}$ 投入する場合には 2 日 間隔で水を入れ換えするのが経済的と衛生的で好まし W.

\section{結 論}

われわれは乳質改善において必ずしも断熱水槽および 冷水装置の物理的効果をもってのみ万全といたしている のではなく, 改善事業の一環として利用しているのであ るが，これなどを設備することによる経済的効果にはみ るべきものがあることを実証することができたので，こ こにこの結果を紹介するとともに本設備を一般農家に広 く推奨普及させたい。

日獣会誌 18 (1965) 
第64回日本獣医公衆衛生学会（東北）期日：昭和38年 9 月 27 日 会場 : 福島市, 県庁講堂

\section{獣肉, 魚肉の電気抵抗度と鮮度について \\ 山口正志* 丹羽与英* 佐藤幸男* 斉藤 毅* 工藤芳雄* 佐藤重作* 鈴木正七* 浜口剛一** 梅沢長一** 木村 広**}

緒論 第 55 回日本獣医公衆衛生学会において，筆者 が試作した電気抵抗測定器で, 獣肉, 魚肉の電気抵抗度 (以下ERと略す)を測定し肉, 魚の鮮度判定が現場にお いて応用できたことについて報告した．さらに筆者は県 衛生部の配意により, 公自衛生院松井先生の指導をらけ た際に海水魚の可食限界 $\mathrm{E}$ Rの決定などについて研究し てはという助言を得た，そして追加研究したのでその成 績を報告する。

実験方法 検査種類はイカ, サバ, イナダ, アジ, マ グロなど 150 件体について検査した。な竹度検査の方 法拉よび保存方法は昨年の本学会で発表したと招りであ る.ただし塩蔵魚のER測定では固定抵抗を $50 \Omega$ とし た。

成績 第 1 報の肉, 魚の E R と揮塩 Nの関係は-0.71 であった。本報告の関係では, 肉, 冷凍魚, マグロなど

* 山形保健所 ** 山形県公衆衛生課
を除いた112件について調査したところ一0.95であった。 また，イカ，イナダ，アジについてERと揮塩N量およ び鮮度についてみると，鮮度良好なるのは E R 指数 45 以 上で揮塩N 13〜 $15 \mathrm{mg} \%$ であり，普通魚は 43〜44の ERで揮塩N 15～20mg\%，要注意魚は 41４2 のER で揮塩 $\mathrm{N}$ 24 $26 \mathrm{mg} \%$ 含み, 初期腐敗魚は 39〜40の $\mathrm{E}$ $\mathrm{R}$ で揮塩 N $30 \mathrm{mg} \%$ 以上であった。 また腐敗魚となると E R 38 以下で $50 \mathrm{mg} \%$ 以上の揮塩Nが含まれていた. また要注意魚加ら初期腐敗に至る場合揮塩 $\mathrm{N}$ の増加は, イカが最も早くついでアジ，イナダの順であった.イカ の手つかみ污染による鮮度低下について調査してみた場 合（軽く 50 回指先で揉み $4^{\circ} \mathrm{C}$ に保存）手つかみにしな いイカより, 次日より鮮度低下の差がみられ3日目で

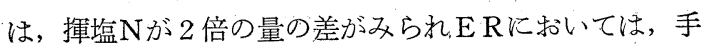
つかみしないイカ 39.5 に対し手づかみしたイカは 37.0 と低下した。

第65回日本獣医公衆衛生学会（中国）期日：昭和38年 9 月 $26 ， 27$ 日 会場 : 松江市, 県庁講堂

\section{食中毒起因ウエルチ菌の自然界に和ける分布}

\section{山県宏*}

最近までウェルチ菌(Clostridium welchii)はガスエソ の主要病原菌であって, 自然界に沉く分布し, その芽胞 は $90^{\circ} \mathrm{C} 30$ 分〜 $100^{\circ} \mathrm{C} 5$ 分という短時間の加熱によってこ とごとく殺滅されると, ほとんど先入観念的に信じられ ていた。したがって $100^{\circ} \mathrm{C} 1$ 時間以上 5 時間にもおよぶ 長時間の加熱に抵抗生残する強力な芽胞を持つ熱抵抗性 変異菌株(Heat resistant variant strain of $\mathrm{Cl}$.welchii) 見逃がされ, それが食中毒の原因菌となることは想像さ えもされなかったのは至極当然であろら．わが国のウ土 ルチ菌食中毒がメジウムを初めとする多くの点で, 欧米 諸国のそれとかなり相違することが明らかとなり，こと に, 欧米の発生事例が劻とんど畜肉和よびその加工品を メジウムとするのに対し, わが国のそれはほとんど魚 介類とその加工品をメジウムとして発生していることは きわめて対照的といえよう。端的にいってウエルチ菌食 中毒の研究史はきわめて浅く, 疫学的臨床的その他 2 , 3の点に関してある程度の検討が加えられたに止まり, な扣多くの点については未解明の現状である. 害際問題

\footnotetext{
* 山口県衛生研究所
}

として食中毒発生の機序を解明しその発生を防止するた めの根底として起因菌である熱抵抗性変異ウェルヂ菌株 (この 1 群の食中毒起因ウエルチ菌株は, 菌体抗原 Somatic antigen によるO凝集反応によって Hobbs type 1 13 に型別分類される) の自然界に和壮る分布, 変動 などを究明把握することが不可欠である。私は 1957 年 以来継続実施中のウェルチ菌食中毒研究の一環として自 然界(ことに人屎, 土壤, 魚介類, 昆虫) に和故る菌の 分布，污染について検討したので報告する.

成樍 土壌：1959 年 5 月から 1961 年 10 月にわたっ て山ロ県下より泥砂サンプルを゙at random に収集し菌 の検出分離を実施した．泥砂サンプル計 756 個より菌 10 株 $(1.32 \%)$ が検出され, 菌の Serotype は Hobbs type 5 および 6 が圧倒的多数を占める.

人屎：1961年 4 月お预よ゙゙ 5 月山口市内の健康者から収 集した faecal sample 186個中その 6 個（3.2\%）より菌 が検出され，その Serotype は Hobbs type 5 および 6 が注とんどを占める。

昆虫( ゴキブリ) : 1959 年および 1960 年の夏期山口市 
内の主として厨房, 排水溝, 畜舎などに掠いて捕獲した ゴキブリ 43 体中その 12 体 (27.9\%) から菌が検出さ れ，その. Serotype は Hobbs type 5 およざ 6 が多数を 占める.

魚介類: 1962 年 4 月から 1963 年 3 月にわたって海産 魚介類（沿岸魚介類, 近海魚介類, 遠洋魚介類) につい て, その水揚げ時に収集したサンプル 500 個について菌 の検出を試みたがまったく陰性であった。

要約 本調查研究は「スクリーニング」の範囲に限局 して実施したものであるが，自然界に抢ける菌の Ecol一 ogy の一端を推定し得るものであり, 従来ウェルチ菌の 保有母体であり,かつ污染源 Contamination sourceとな ると考光られていた土䁃からの検出率は予想されていた ものよりははるかに少なく, むしろ, 人を含めての動物 および昆虫から高率に検出されることは注目すべき点で あろう. すなわち, 污染源として従来から考穴られてい た土壌はもちろんであるが，むしろそれ以上に人の無症 状保菌者 Human symptomless carrier 含めての動物 保菌者や昆虫保菌者に関心を払うとともに, その保有菌 型と発生事例の起因菌型との関連性について注目するこ
とが疫学的見地からも不可欠である. 水揚げ時に収集し た海産魚介類から菌が検出されなかったことは一もした とえ検出されるにしてもその頻度はきわめて稀であらら 一この菌による魚介類の污染は, 揚陸後摂食されるるで のあらゆる過程に和いて, 人特よび動物保菌者, 昆虫な ぞを介して污染されるものと推定される。検出菌の Serotype が圧倒的に Type 5 拈よび Type 6 が多いこと は注意を惹く点であって, 過去数年来日本各地で報告さ れた発生事例の菌型が Type 5 拉よび Type 6 が多いこ とと照合して, きわめて與味深い。これら一連の調査研 究棌打いて検出された菌株の Serotype とわが国自然界 各地の菌型分布, および過去, 将来の発生事例とその原 因菌型との間の疫学的諸問題, 関連性等々については, 今後の自然界全般にわたる広沉かつ詳細な系統的調査成 績の蓄積と,な括しばらくの時間的経過汇亲って論考す べきであるが，いずれにしてる，ここに述べた知見は， ウェルチ菌食中毒に护ける污染源と污染経路の問題につ いて疫学的考察を加える場合にきわめて興味に富も多く の資料と示唆を提供するものである.

\section{第66回日本獣医公衆衛生学会（九州）期日 : 昭和38年10月29日 会場 : 大分市, 林業会館ホール}

\section{鼠の駆除対策について}

\section{谷川之弥*}

最近とくにビルなどの所謂高層建築物内に鼠のチョウ リヨウが著しく，害を受けているとの論議がなされてい る折柄われわれも福岡市の 1 鼠生息高密度地帯と思われ る那珂川畔叔よびその隣接家屋を選定し今後の対策けた め基礎調査を実施した。

対象地区は総延長約 $900 \mathrm{~m}$ で上流から䇾島橋, 稻荷 橋, 柳橋および住吉橋があるが簧島橋より下流 $264 \mathrm{~m}$ を $\mathrm{A}$, 稲荷橋上り上流 $276 \mathrm{~m} \mathrm{~B}$, 稻荷橋上り下流 $279 \mathrm{~m}$ をC，住吉橋をはさんだ $76 \mathrm{~m}$ をD地区と扔のおの区分 した．A，B地区は旅館料亭など約 55 户が河岸に直面 し，C地区は県道を距てて柳橋連合市場約 140 戸があ る.

とくにC地区は塺芥の投亲が多くまた石坦孔护よび市 場からの下水管が開口しているためぼブネズミの生息場 所として最も適した環境にある。

調查の事前作業として慨の選定試験を 3 種類の饂（生 サッマイモ, 豚皮, 天婦羅) について行なった結果生サ ッマイモの引去率が最も高く対象区間に和ける鼠の主な 喍好が生サッマイモであることが実証された。生息数の 推定には Hayne 杉山の推定法を用いた. 捕殺罢はA, $\mathrm{B}, \mathrm{C}$ 地区のおのおの $150 \mathrm{~m}$ 内に $2 \mathrm{~m}$ 間隔で川床に 1 列 * 福岡市福岡保健所

日獣会誌 18 (1965)
に配置した。捕殺は 2 月 27 日，28日， 3 月 1 日， 2 日の 4 日間にわたって行なったが, その結果捕殺個体はC地 区のみにみられAB地区では生息のしるしがみとめられ たにすぎない，このため 3 月 1 日にB地区の䍔 40 戸を゙ $\mathrm{D}$ 地区へ移動させ 3 月 $2,3,4$ の 3 日間で捕鼠した結果 C地区と類似の結果が得られた。この結果鼠生息と環境 との関係に有意の差を認めた. 以上の調査後黄燐剤( ト ルペット) を混入した毒慨を用いて駆除を実施した。毒 慨施用量は理論值, すなわち $4.5 \mathrm{mg}$ 亿生息推定数妾た は推定生残数を乗じたものの 10 倍前後を用いA, B , C 拈よびD地区に配置し毎日消失数を確認補充しつつ 5 日 後にすべて回収した．その引去数は C D 地区でほぼ同数 を示し推定された生残数が比較的正しいことを間接に示 している.

毒䬲駆除の 2 日後の 3 月 11 日から 15 日にかけて効 果判定のため逐日捕鼠をC，D地区について行なった結 果，D地区ではかなりの効果がみられたにもかかわらず C地区では前回捕鼠時の推定数を上回まわる結果となっ ている.このことは河岸と人家との交流がとくにC地区 に杼いてはD地区に比し著しい結果と思われる。

さらにC地区河岸で捕獲された鼠の剖見によればクマ リン症状と判定されることからも河岸への侵入を示す 1 
証左である．以上のことから河岸の鼠を駆除するには家 屋からの鼠の侵入を考慮して隣接家屋と同時にこれを行 ないまた駆除区と非駆除区の境界は環境的に隔絶された 場所を選定ずべきことが明らかとなった。

河岸の調查と同時に A, B, C地区内の家屋についても 抢の括の10戸， 4 戸，8 戸を選んで罠による基礎調查後全 家屋にクマリン製剤による駆除を実施したが，とくにC
地区の市場に主力を注ぎ 3 月 4 日から 1 カ月間継続して 実施した。

なおこのほかアンケートによる主観調査 70 件につい て生息状況和よび被害状況などについて調查した結果添 とんぞ実害を認めない程度にまで減少している。

このことは該環境下での同時駆除による結果の表われ であり今後の駆除対策上の重要な指針を得た。

第67回日本獣医公衆衛生学会 (東京) (シンポジゥム)

期日 : 昭和 39 年 2 月 23 日 会場 : 東京都, 赤坂保健所講堂

\section{日本獣医畜産学会昭和 38 年度褒賞論文要旨}

第 1 回日本獣医畜産学会 (東北) 期日 : 昭和 38 年 9 月 27 日 会場 : 福島市, 県庁講堂

\section{若令肥育素牛の放牧育成について \\ 吉根浩太郎* 丹 治 健 吉*}

草地経営の一環として，草の利用による肉畜造成が各 地で行なわれるようになってきたが，この種の経営には 未だ種々の問題点があり安定していない，そこで当所は 昭和 37 年度から肉用素牛の放牧育成を実験的にとり入 れ, その間, これらの問題点を把握するため若干の調査 を行なった。

放牧に利用した家畜は 22 頭の黒毛和種雄犢で, 日令 は生後 100 日から 210 日までのものを 4 群に分けて調查 した.

管理の方法は, 購買後 20 日の準備期間を経て, 11/6 $\sim 26 / 10$ の生草期間中, 場内山林等の未利用地, 利用跡 地等を主々する 5 牧区の昼夜放牧を行ない，この間濃厚 飼料を無給与とした。

なお，準備期間中に全頭去勢を行なっだ.

全放牧期間に执ける発育は, 体重で平均 $46.7 \mathrm{~kg}$ の增 を示したが，個体別には，日令に関わりなく，最低 16.6 $\mathrm{kg}$, 最高 $76.5 \mathrm{~kg}$ と増体に巾が認めら机ることから，こ の種の集団理では, 個体差の追及と利用牛の選定が経営 上問題となるものと思われる.
また，日令別の增体は，4群中幼令のものから，35.3 $\mathrm{kg}, 41.8 \mathrm{~kg}, 50.7 \mathrm{~kg}, 60.8 \mathrm{~kg}$ と順次良好となり, 放牧に 対する適応性も考慮し， 6 カ月以下の幼令のものには補 助的な保護管理を要するものと思われる.

次洔期別の発育は 7 月下旬から 8 月下旬の間を除い て，各月それぞれ $0.3 \mathrm{~kg}$ から $0.63 \mathrm{~kg}$ の増を示したが， 上記極暑期はわずかに $0.09 \mathrm{~kg}$ の增に過ぎず，この期間 放牧を続行するには庇蔭施設あるいは草生草質等の相関 的な配慮が必要と思われる。

また, 以上の各増体の状沉を, 和牛の正常発育範囲と 比較すると, 100 日から 160 日令までのものは雄の下限 飞近く上向し，それ以上のものは雌の上限と雄の下限の 中間を辿って上向し，ともに $7 \sim 8$ 月に停滞を示してい る.

これらの放牧牛は, 終牧後継続試験牛 3 頭を残し19頭 の払下 (入札制) を行なったが, その精算の結果, 輸送 費を含む購買価格, 準備期間に打汓る補助飼料費, 消耗 品費, 去勢料等を差引き, 野草, 残草利用による粗収益 として，81,721 円を得た。

* 福島県牧野事務所 